\title{
Late Ordovician rostroconchs (Mollusca) from fluvial erratics in northwestern Europe
}

\author{
Jan Ove R. Ebbestad, Freek Rhebergen \& AleXander P. Gubanov
}

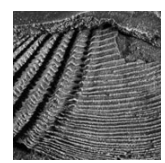

\begin{abstract}
This paper describes 3 species of ribeirioid and 2 species of conocardiid rostroconchs from fluvially transported erratics in the Dutch-German border area. The material probably stems from Ordovician deposits of the North Estonian Confacies Belt. The ribeirioid specimens from the Haljala group of erratics (Sandbian 2) are represented by Tolmachovia sublirata sp. nov., Beukeria plicata gen. nov. sp. nov. and Ischyrinia viator $\mathrm{sp}$. nov. The single specimen of Tolmachovia is hitherto the youngest occurrence of this genus and the first in Baltica. The presence of subordinate radial ornamentation is added to the emended diagnosis of the genus. The new genus Beukeria is an ischyriniid rostroconch with an elongated conch, two thick pegmas and a plicate shell posterior to vertical axis. Ischyrinia viator is similar to the coeval I. norvegica Soot-Ryen, 1960 but this has a ventrolateral sinus that is subparallel to the dorsal axis. Conocardiid specimens from the Pirgu Öjlemyr chert (Katian 4) are represented by Bitrigonocardia lindstroemi (Isberg) and Pojetaconcha costulata sp. nov. The identification of Bitrigonocardia lindstroemi is circumstantial as the type specimens are missing, but as understood here new details of morphology and ornamentation are given. Pojetaconcha is for the first time recognized outside Laurentia and Australia. Pojetaconcha costulata sp. nov. is distinguished by 14 or 15 broad and flat-topped radial ribs on the body and snout and compares closely with the Chazyan P. alabamensis (Pojeta \& Runnegar, 1976), USA. Ischyriniids occur mainly in Baltica with Ischyrinia migrating into Laurentia. A general exchange of Bitrigonocardia and Pojetaconcha is seen between Laurentia and Baltica. - Key words: ribeirioid rostroconch, conocardiid rostroconch, ischyriniid rostroconch, Ordovician, fluvially transported erratics.
\end{abstract}

\begin{abstract}
EBBESTAD, J.O.R., RHEBERGEN, F. \& GUBANOV, A.P. 2017. Late Ordovician rostroconchs (Mollusca) from fluvial erratics in northwestern Europe. Bulletin of Geosciences 92(4), 405-438 (22 figures, 4 tables). Czech Geological Survey, Prague. ISSN 1214-1119. Manuscript received May 13, 2017; accepted in revised form September 20, 2017; published online December 6, 2017; issued December 31, 2017.
\end{abstract}

\begin{abstract}
Jan Ove R. Ebbestad, Museum of Evolution, Uppsala University, Norbyvägen 16, SE 75236 Uppsala, Sweden; Jan-Ove.Ebbestad@em.uu.se • Freek Rhebergen, Slenerbrink 178, NL-7812 HJ Emmen, the Netherlands; freek.rhebergen@planet.nl•Alexander P. Gubanov, Museum of Evolution, Uppsala University, Norbyvägen 16, SE 752 36 Uppsala, Sweden; alexander.gubanov@pal.uu.se
\end{abstract}

Rostroconchs are a small but morphologically diverse group of molluscs in the Lower Palaeozoic, characterized by an essentially univalved conch with a pseudo-bivalved appearance where the two halves of the shell are fused along a hinge-line dorsally (Pojeta et al. 1972, Pojeta \& Runnegar 1976). Anteriorly there may be a gape where the foot extended and additional openings are presented ventrally and posteriorly. The characteristic protruding posterior tube with a terminal opening is called the rostrum which in part gave the name to the group (Pojeta et al. 1972). Currently three orders are recognized (but see Engeser \& Riedel 1996), the Ribeirioida found through the early Cambrian to the early Silurian, the Conocardiida occurred from the Middle Ordovician to the late Permian and the Permian Anetshelloida (Pojeta \& Runnegar 1976, Pojeta 1987, Hoare \& Plas 2003, Mazaev 2012, Amler \& Rogalla 2013).
Rostroconchs are presumed to have occupied infaunal to semi-infaunal habitats (Pojeta \& Runnegar 1976, Runnegar 1978, Pojeta 1987, Mazaev 2012, Amler 2016). The infaunal mode of life is reflected in the often narrow, elongated body shape, a recurring morphological theme among Palaeozoic infaunal molluscs called scaphopodization by Peel (2006). The protoconch in ribeirioid rostroconchs, as known from Pinnocaris, is an isostrophic shell coiled exogastrically, i.e. the coil is directed anteriorly while expanding posteriorly (Peel 2004). The conocardiid protoconch is cone or cup-shaped and seemingly endogastrically coiled (i.e. the coil is directed posteriorly while expanding anteriorly) (Pojeta \& Runnegar 1976, Peel 2004). During growth the conocardiid protoconch is enveloped by the incurving umbos of the growing shell and therefore often obscured. 


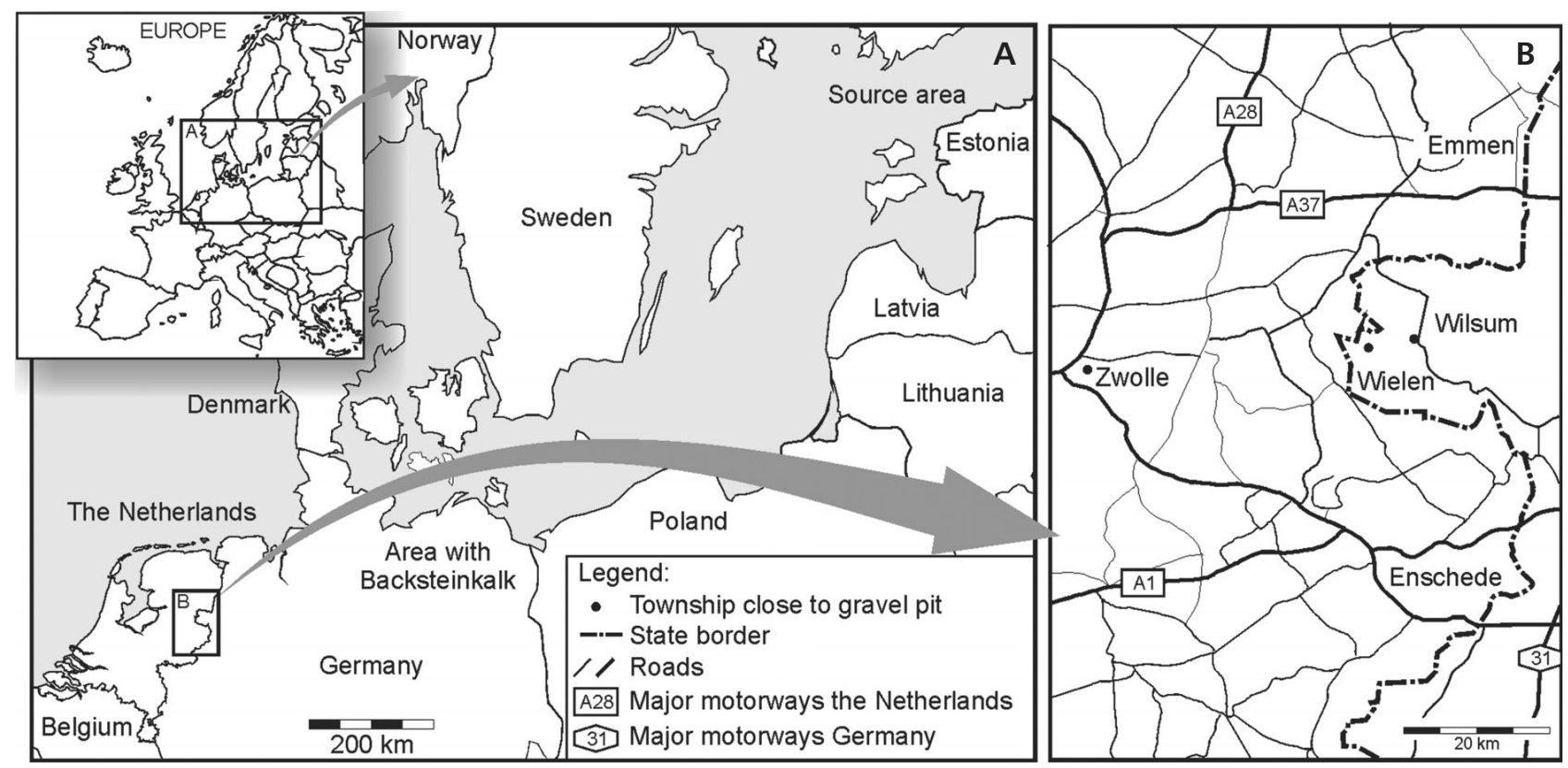

Figure 1. Map of northern Europe showing area of investigation (A) and localities where the fluvial erratics in this study was found (B). Coordinates for the pit near Zwolle: $55^{\circ} 33^{\prime} \mathrm{N}, 6^{\circ} 54^{\prime} \mathrm{E}$. Coordinates for the pit near Wilsum: $52^{\circ} 31^{\prime} \mathrm{N}, 6^{\circ} 30^{\prime} \mathrm{E}$. Coordinates for the pit near Wielen $52^{\circ} 32^{\prime} \mathrm{N}, 6^{\circ} 44^{\prime} \mathrm{E}$.

This paper describes a collection of well-preserved rostroconchs from fluvially derived erratics collected in the Dutch-German border area (Fig. 1). Hitherto Ordovician rostroconchs from Baltica are only known from the Late Ordovician with 12 species recognized, 8 of which are ribeirioids and 4 are conocardiids (Amler \& Rogalla 2013, this paper; Fig. 2). Four of these are new species described herein (including a new genus).Together with better material of the known species this work highlights morphology, variability and diversity of these taxa.

\section{Material and geological setting}

The rostroconchs described in this paper come from pebbles and cobbles collected through many years mainly by F. Rhebergen (Rhebergen 1994) from a number of sand and gravel pits in the border area between the northern Twente district in the province of Overijssel in the eastern Netherlands and in the adjacent part of the county of Bentheim, state of Lower Saxony, Germany (Fig. 1). Surface sediments in north and northwestern Germany and the Netherlands are late Cenozoic deposits (Miocene to early Pleistocene), generally believed to be fluvially derived through drainage material from the Baltic shield. This was transported down the present Baltic Sea in an enormous Baltic fluvio-deltaic river system known as the Eridanos (Overeem et al. 2001). The river system was destroyed by the middle and late Pleistocene glaciers.

Rhebergen (2009) and Van Keulen et al. (2012) distinguished between several types of Ordovician fluvial errat- ics deposited by the Eridanos in the Dutch-German border area. All erratics are secondarily silicified limestone which derive from different regions and have different transport histories and ages although their faunal assemblages suggest a provenance of the North Estonian Confacies Belt (Tab. 1; see discussion in Rhebergen 2009).

The Lavender blue chert (Lavendelblaue Hornsteine) is rare and according to the fossils it is suggested that they represent partly the Haljala and Keila stages (late Sandbian-early Katian) and partly the Pirgu Stage (late Katian). More abundant is a varied Pirgu group of erratics (Rhebergen 2009). One type is called the brown Pirgu chert/limestone (Brauner Pirgu-Hornstein) which stands out by its dark brown colours and fossils preserved with a porcelain type quality. This rock is rich in silicified demosponges sponges and calcareous algae but depleted in trilobites. Neither the Lavender blue chert nor the brown Pirgu chert contains rostroconchs (Tab. 1).

This study is based on 33 rostroconch specimens in the Rhebergen collection. Most of them are preserved as both internal and external moulds. Half of the specimens come from the so-called Haljala group of erratics which are represented by several types of yellowish-grey cherts with fossils usually preserved as casts. Often the core of the erratic is solid and surrounded by an outer porous and weathered zone. Rostroconchs are represented by Tolmachovia sublirata sp. nov., Beukeria plicata gen. nov. sp. nov. and Ischyrinia viator sp. nov. Other fossils indicate broadly the Haljala Stage (Jöhvi and Idavare substages, Sandbian 2) age (Tab. 1, Fig. 2). In the glacially derived erratics in northern Germany broadly similar type cherts are 


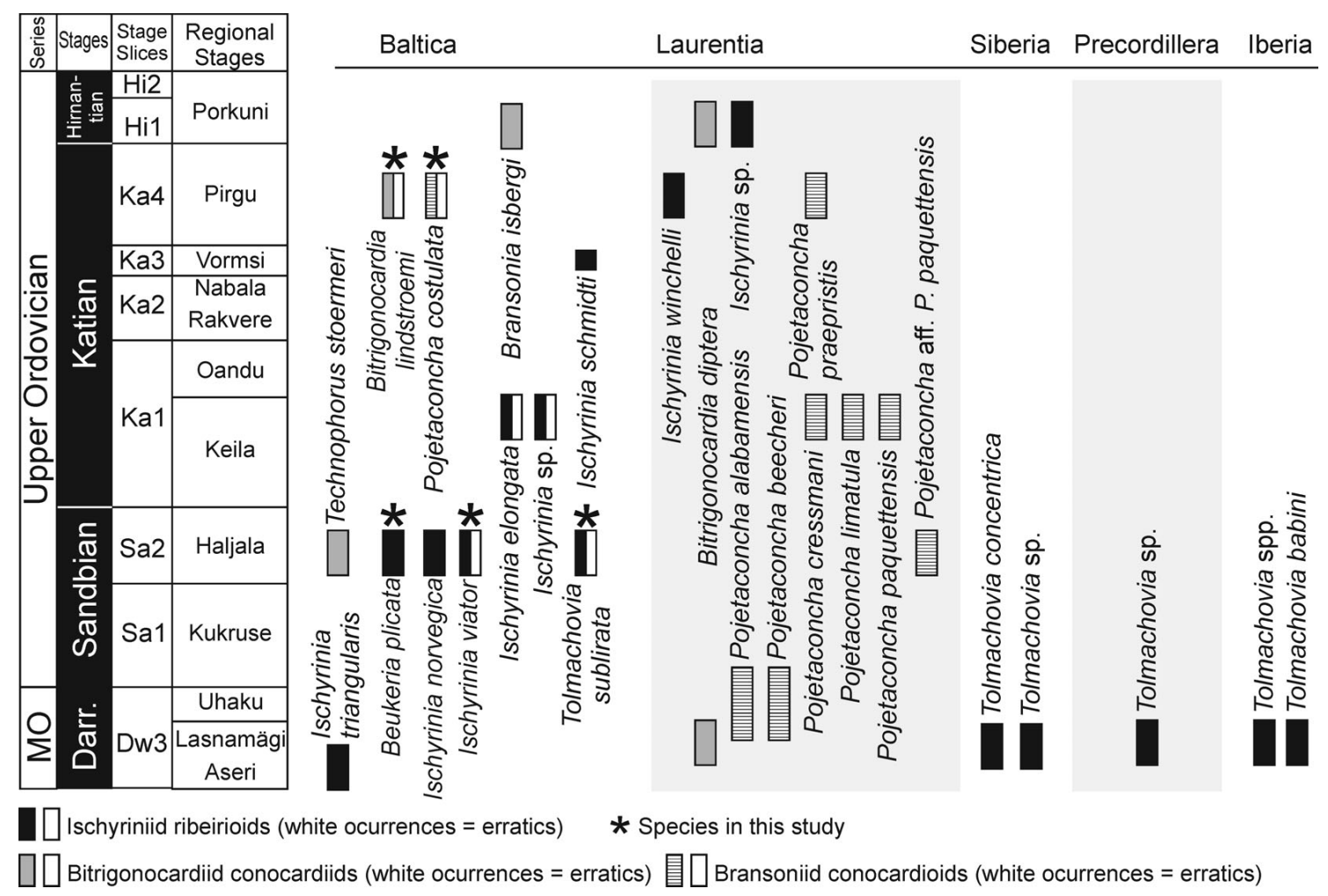

Figure 2. Stratigraphical distribution of all known rostroconch species in Baltica, and that of Tolmachovia, Ischyrinia, Bitrigonocardia, and Pojetaconcha elsewhere in the Ordovician. The Australian record of Pojetaconcha in the Katian (see Table 4) is omitted owing to space. Ordovician stratigraphy based on Bergström et al. (2009).

collectively called Backstein Limestone (Backsteinkalk), but these show a different fossil content (Van Keulen et al. 2012). The material described herein will therefore be referred to as Haljala group erratics or Haljala erratics following Rhebergen (2009).

The second half of specimens presented here come from a very common Pirgu group erratic, i.e. pieces of cherts widely recognized as the Öjlemyr chert (Öjlemyrflint), a term that includes the Öjlemyr Limestone (Öjlemyrkalk) which simply is the white weathered crusts zone of larger fragmented Öjlemyr chert blocks (Van Keulen et al. 2012). Rostroconchs are represented by Bitrigonocardia lindstroemi (Isberg, 1934) and Pojetaconcha costulata sp. nov. Other fossils indicate the Pirgu age (Katian 4) (Tab. 1, Fig. 2), but the assemblage differs from that of the brown Pirgu chert discussed earlier (Van Keulen et al. 2012).

The relatively dense concentration of silicified fluvial Ordovician erratic in the Dutch-German border area from only a few time slices is difficult to explain. The material must have been silicified already in the Baltic region, as the carbonate would have been dissolved before the material was deposited by the Baltic river System. Middle and late Cambrian, Early and Middle Ordovician, Silurian and younger Devonian blocks are as yet absent in the study area, which is one of the essential differences between the fluvial and glacially transported late Pleistocene erratics. The range of lithologies in till deposits is far more varied, including blocks of the entire Cambrian to the Silurian. Additionally, the provenance of the glacially derived material is more to the west, deriving from the Central Scandinavian Confacies Belt.

\section{Biogeography}

Amler \& Rogalla (2013) made an extensive review of the biogeographical distribution of Early Palaeozoic rostroconchs, and the material presented here adds some new information. The material described herein derives most likely from the North Estonia Confacies Belt, representing deposits in shallow water shelf areas in a low latitude position during the Sandbian and Katian. The samples represent both ribeirioid and conocardiid rostroconchs of which most have a known previous evolutionary history. As pointed out by Amler \& Rogalla (2013) the Tremadocian occurrences of Tolmachovia are restricted to low latitude areas of Australia and Argentina. They included here T. crassa Thoral, 1935 from France as a high latitude exception to this pattern. However, the occurrence of the taxon 
is better placed in Floian strata which would give a distribution into higher latitudes (Armorica) of Tolmachovia first during this time slice (Tab. 2, Fig. 2). The Darriwilian sees a broader distribution of the genus in low latitude areas of peri-Gondwana and high latitude areas, with an introduction to Siberia for the first time. Tolmachovia is not found in Laurentia, which otherwise show a close faunal similarity to Baltica and partly Siberia in the gastropod faunas at this time (Ebbestad et al. 2013). The occurrence of Tolmachovia in Baltica may be a result of migration from Siberia although the faunal tie for the gastropods is weak (Ebbestad et al. 2013). Most likely there is a discrepancy in the distributional data due to lack of records.

The distribution of the ischyriniid ribeirioids Ischyrinia and Buekeria as well as the conocardiid Bitrigonocardia shows a much more consistent pattern and similar to that shown by Amler \& Rogalla (2013). The major new addition is the clear dominance of the ischyriniid branch in Baltica during the Sandbian and Katian with Ischyrinia finding its way to Laurentia in the late Katian and Hirnantian (Tab. 3, Fig. 2). Only three occurrences exist for Bitrigonocardia (Fig. 2) with a large gap between the Darriwilian record of $B$. diptera (Salter, 1851) (also recorded in the Hirnantian), and the occurrence in the late Katian of Baltica. Although the tie points are few it may suggest the same close exchange between Laurentia and Baltica already seen among other taxa at this time.

Pojetaconcha is dominantly a Laurentian taxon in the Sandbian and Katian, albeit with the exception of one occurrence in the Katian of Australia (Tab. 4, but not shown in Fig. 2). The distributional pattern is otherwise similar to that of the ischyriniids and Bitrigonocardia.

\section{Morphology}

Figure 3 shows the descriptive terminology applied in this paper for the ribeirioid (Fig. 3A-F) and conocardiid (Fig. 3G-K) rostroconchs. Most of the terminology comes from Pojeta \& Runnegar (1976) and Pojeta (1987) with some terms from Caldwell \& Chatterton (1995) and Rogalla (2005). Rostroconchs have several openings in their shell, and the term gape is used to specify the main anterior, ventral and rostral openings (Pojeta \& Runnegar 1976). In the hippocardioid conocardiid taxa the posterior gape is reduced to a small opening at the end of the rostrum which is called the rostral orifice. Similarly, the restricted opening of the body tube (see below) is called the ventral orifice. In ribeirioid rostroconchs the anterior commissure tends to be closed or appear as a thin slit, and they do not develop the distinct snout of the hippocardiid rostroconchs.

The imaginary line between the anterior and posterior ends of the dorsal part of the conch was called the dorsal axis by Rogalla (2005), while the imaginary line from the umbo to the ventral margin was called the vertical axis, and these were used for orientation, morphological descriptions and measurements. This terminology is applied to all rostroconch species described here (see Fig. 3F).

Ribeirioid rostroconchs have one or two pegmas, which are thick or thin plates across the shell on the dorsal side, firmly binding the shell halves together. These are attachment sites for muscles. Pegmas leave deep notches in the internal moulds, and although these are not the actual pegmas they are called so here for descriptive purposes. The entire dorsal median body framed by the pegmas and carrying the umbo(s) is called the umbonal body (umbonal filling of Pojeta et al. 1977, umbonal cavity of Pojeta 1987) to distinguish the physical part of the internal mould and not the cavity it represents within the conch. The lower limit of the umbonal body coincides approximately with the base of the pegmas.

The 'tube of ventral gape' of Caldwell \& Chatterton (1995, p. 808) in hippocardiids was called a tube by Pojeta et al. (1972) and Pojeta \& Runnegar (1976) and tube shaped pipe (röhrenförmiger Tubus) by Rogalla (2005) and is here called the body tube to distinguish the placement relative to the tripart shell areas. As the only position is ventral to the body, including 'ventral' is redundant. The body tube is an extension or continuation of the primary carina (Caldwell \& Chatterton 1995) in some conocardiids and is seen as an infilling on internal moulds.

The primary carina in the conocardiid family Hippocardiidae Pojeta \& Runnegar, 1976 and Pseudobigaleaidae Hoare et al., 2002 is present where the sheet-like hood is attached. The hood itself derives from a separate shell layer than the conch, produced from the mantel extension that is manifested as the body tube on internal moulds (see Pojeta \& Runnegar 1976, pp. 10, 11; Pojeta 1987 , p. 362). The broad band that is the primary carina runs from the umbo to the ventral margin. The primary carina is widest just at the ventral margin. When the hood is removed the surface of the carina shows distinct lunular growth lines (pseudo lunulae) corresponding to the growth lamella of the hood (Figs 17A, C, 18E). Pseudo lunulae are always with the convex side towards the umbo and the concave side towards the ventral orifice (Rogalla 2005). Amler (2016) coined the term lunulazone for this band in a pseudobigaleaiid, which emphasizes a feature of the primary carina and as such is a supplement to the descriptive morphology (primary carina channel in Wagner 1997, Schleppenrinne in Rogalla 2005). However, the name does not necessarily replace 'primary carina', which is the term preferred herein for the sharp ridge; Pojeta \& Runnegar (1978) and Pojeta (1987) defined the carina as an angulation of the umbo or a sharply defined rib associated with the umbonal ridge. By analogy, but not necessarily homology, the expression of a single ridge on ribeirioiids is called a primary carina (Wagner 1997). 
Table 1. Type of erratics discussed herein indicating age and key fossil content. For typology of the various erratics see Van Keulen et al. (2012).

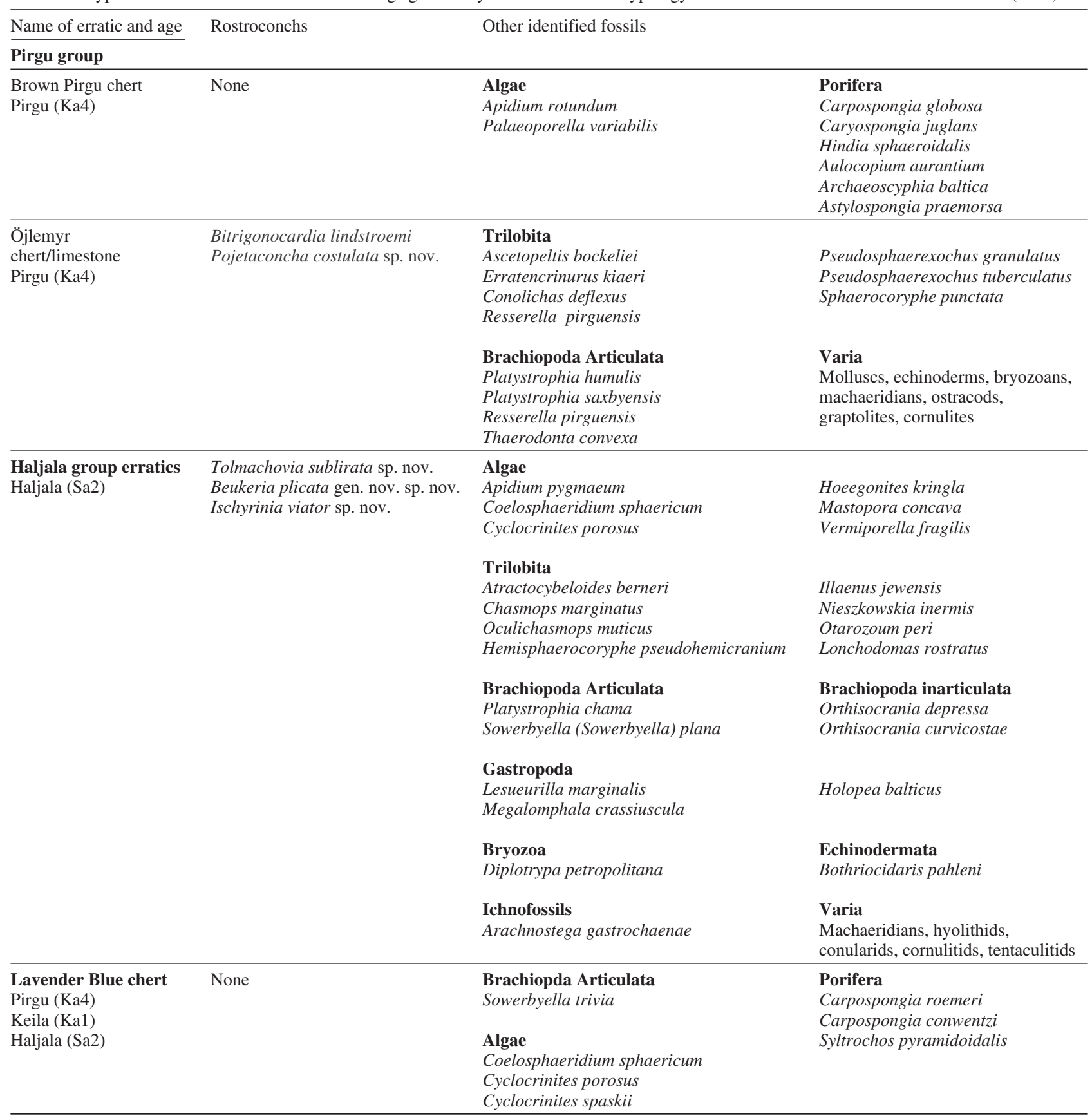

Rogalla (2005) pointed out that the outer shape of the conch in hippocardiids is strongly affected by the direction of the primary carina and distinguished between prosocline, opisthocline and orthocline conchs and hoods (Schleppenverlauf: Rogalla 2005; Rogalla \& Amler 2006a, b). In prosocline conchs the primary carina is angled backward from the ventral margin to the umbo relative to the vertical axis. In opisthocline conchs the primary carina is angled forward from the ventral margin to the umbo relative to the vertical axis. In orthocline conchs the direction of the primary carina is parallel or sub-parallel relative to the vertical axis (see Fig. 3G).

Rogalla (2005) also detailed the shape of the ventral margins of the snout and body (straight, concave, convex, etc.) in hippocardiids. The shape of the ventral margin of Bitrigonocardia lindstroemi (VM II in Fig. 3) is weakly concave and the convexity is developed evenly around the centre of the arch described by the margin. The margin is sloping ventrally relative to the dorsal axis and this combination of features can be called an evenly convex, 
divergent margin (= gleichmäßig konvex divergierend in Rogalla 2005). Several categories of expression of the rostral areas in hippocardiids were also defined by Rogalla (2005), based on a ventral view. Thus, Bitrigonocardia lindstroemi displays a rostral area with a concave surface and an acutely pointed posterior development, which can be called a pointed concave rostral area (= spitz konkav in Rogalla 2005).

Rogalla (2005) further distinguished different shapes and development of the snout (in lateral view), such as a triangular snout (triangular), a nose-like snout (nasut), straight wing-like (geradlinig alaeform) and concave wing-like (conkav alaeform). The translated terms outlined above are used herein in the descriptive part.

\section{Systematic palaeontology}

The specimens described or mentioned herein are deposited at the Naturalis Biodiversity Centre (acronym RGM), formerly the Rijksmuseum Geologie en Mineralogie, and the Palaeontological collections at the Natural History $\mathrm{Mu}-$ seum in Oslo, Norway (acronym PMO). Consult Figure 3 for terminology used in the descriptive sections. Specimens where coated with ammonium chloride sublimate prior to photography.

Kingdom Mollusca Linné, 1758

Class Rostroconchia Pojeta, Runnegar, Morris

\& Newell, 1972

Order Ribeirioida Kobayashi, 1933

Superfamily Ischyrinioidea Kobayashi, 1933

Family Ischyriniidae Kobayashi, 1933

Remarks. - Wagner (1997) distinguished two riberioidderived clades, one represented by posteriorly elongated forms like Pinnocaris Etheridge, 1878 and Technophorus Miller, 1889 with a single thin anteriorly placed pegma and a second represented by Tolmachovia Howell \& Kobayashi, 1936 and Ischyrina Billings, 1866 generally with two thick pegmas (synapomorphy) and a shorter posterior body. Consequently the Ischyrinioida of Pojeta \& Runnegar (1976) was recognized as a family within the Ribeirioida by Wagner (1997).

\section{Genus Tolmachovia Howell \& Kobayashi, 1936}

Type species. - By original designation, Tolmachovia concentrica Howell \& Kobayashi, 1936, p. 60, presumably from the Darriwilian (Dw2-Dw3) Moyero River Formation at the Moyero River, northwestern Siberia.

Emended diagnosis. - (translated and emended from Gutiérrez-Marco \& Aceñolaza 1992, p. 1804 with additions from Wagner 1997). Ischyriniid with symmetrical conch around vertical axis, a single umbo, anterior gape as thin slit or closed, ornamentation predominantly comarginal, sometimes with sparse radial elements restricted to the posterior half of the shell or subordinate radial ornamentation between comarginal ornamentation on larger part of conch.

Remarks. - Gutiérrez-Marco \& Aceñolaza (1992) emended the diagnosis of Tolmachovia, based on Pojeta \& Runnegar (1976) and Pojeta et al. (1977), to emphasize the prominent comarginal ornamentation only occasionally with subordinate radial ornamentation in the posterior part of the shell. The Iberian Middle Ordovician forms (Fig. 2, Tab. 2) seem to have exclusively the comarginal component which Gutiérrez-Marco (1997) found incompatible with a placement of the genus in the Technophoridae Miller, 1889 where radial ornamentation is diagnostic. Wagner (1997) moved Tolmachovia from the Technophoridae to the Ischyrinidae, but not because of the radial ornamentation. Instead he pointed out the short body and two pegmas shared by members of the Ischyrinidae compared to elongated bodies and a single anterior pegma in the Technophoridae. The new taxon presented herein show subordinate radial ornamentation on the preserved parts of the shell, prompting a slight emendation of the diagnosis of Tolmachovia.

Tolmachovia is currently known from 8 named species (Tab. 2) as well as a number of other Ordovician species in open nomenclature, mainly from the Darriwilian of Iberia (Gutiérrez-Marco 1997, Sá 2008) but also from the Darriwilian of Argentina (Sánchez 1998). The oldest taxa are known from Australia, Argentina and France and show a general early distribution in low latitude areas and a subsequent spread into high latitude areas during the Lower Ordovician (Amler \& Rogalla 2013). Australia belongs to the low latitude province and Argentina and France the high latitude province following Harper et al. (2013).

\section{Tolmachovia sublirata sp. nov.}

Figure 4

Holotype. - An external mould (RGM.1332175) from the Haljala group erratics (Haljala Stage) at Zwolle, the Netherlands. This is the only specimen available.

Figure 3. Descriptive terminology applied in this paper for the ribeirioid (Fig. 3A-F) and conocardiid (Fig. 3G-K) rostroconchs. Terminology based on Pojeta \& Runnegar (1976), Caldwell \& Chatterton (1995) and Rogalla (2005). 


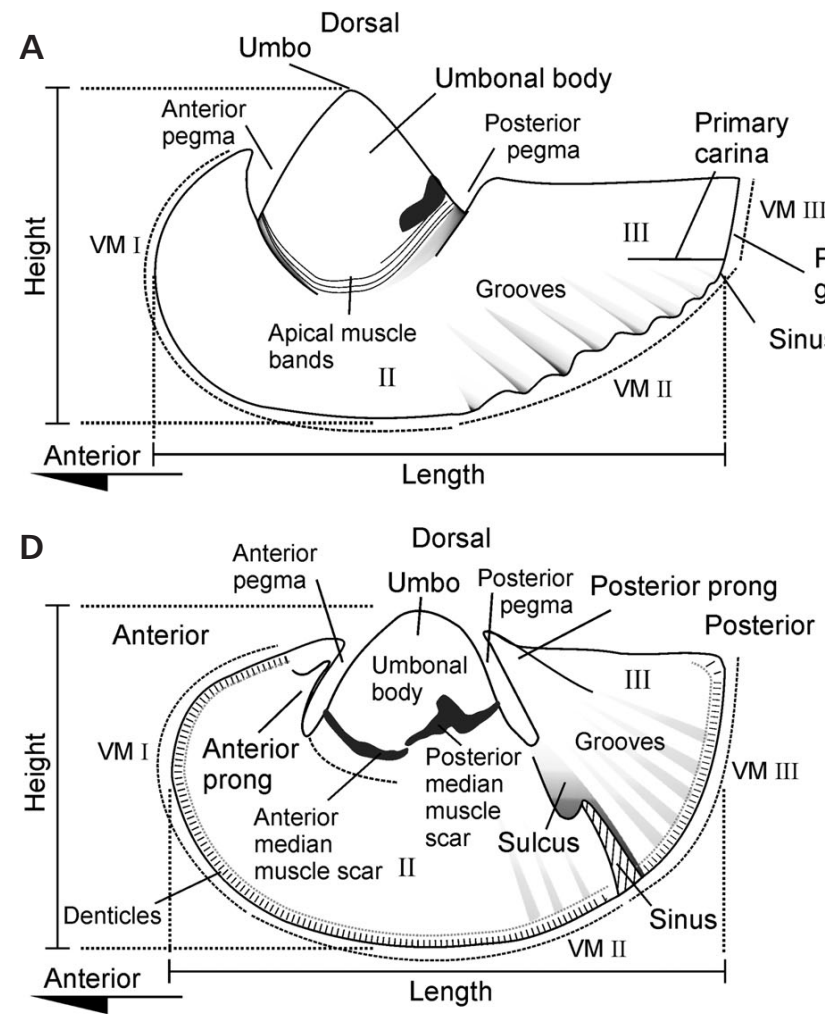

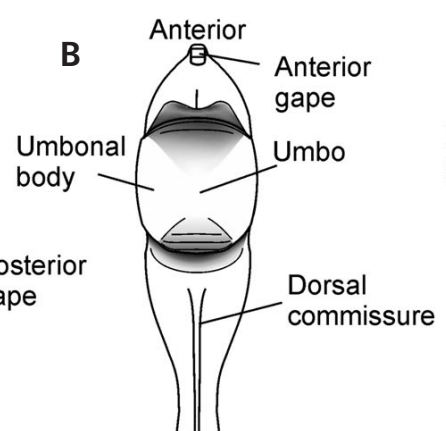

Posterior
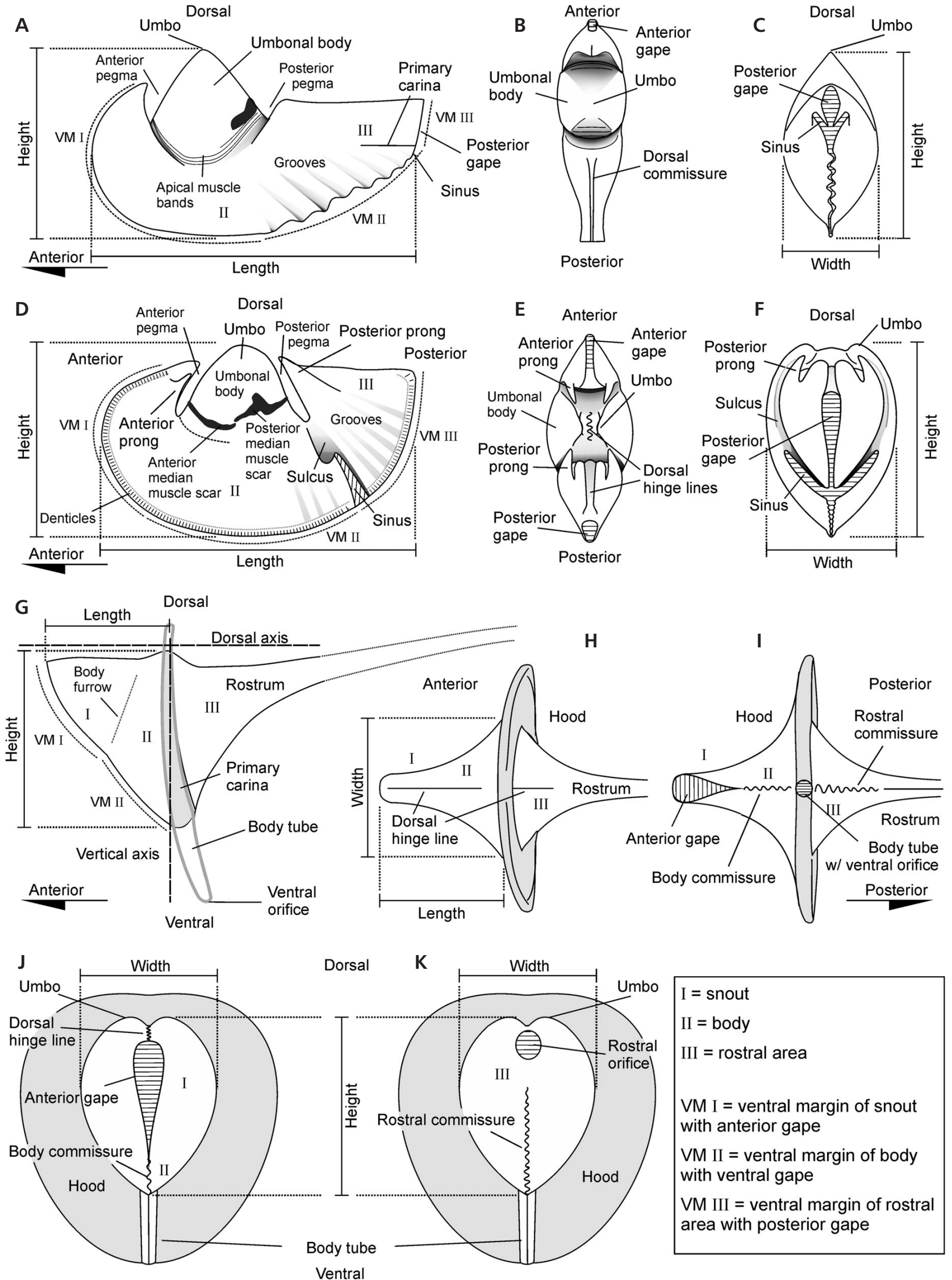

K

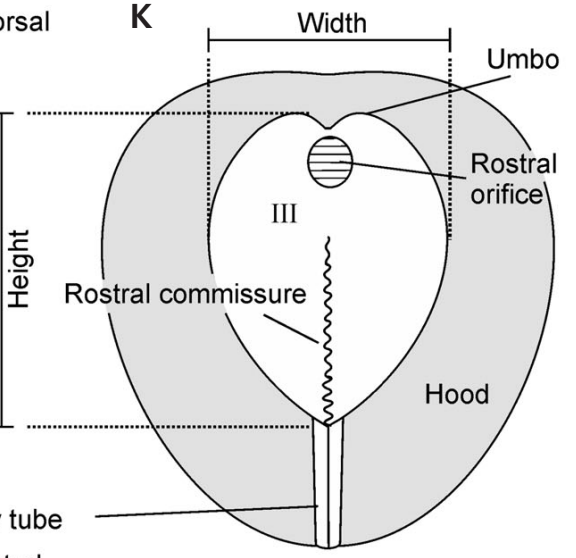

$\mathrm{I}=$ snout

II = body

$\mathrm{III}=$ rostral area

VM I = ventral margin of snout with anterior gape

VM II = ventral margin of body with ventral gape

VM III = ventral margin of rostral area with posterior gape 
Table 2. Alphabetic list of Ordovician species of Tolmachovia and their stratigraphical and geographical occurrences. Stage Slices follow Bergström et al. (2009).

\begin{tabular}{|c|c|c|c|}
\hline Taxon & Occurrence & Local stages & Stage Slices \\
\hline Tolmachovia andina Harrington, 1938 & San Bernando Formation, Argentina & 'Arenigian' & $\operatorname{Tr} 3$ \\
\hline Tolmachovia babini Gutiérrez-Marco, 1997 & Estena Formation, Spain & Oretanian & Dw2 \\
\hline Tolmachovia belfordi Pojeta et al., 1977 & Tomahawk Formation, Australia & Lancefieldian & $\operatorname{Tr} 1$ \\
\hline Tolmachovia concentrica Howell \& Kobayashi, 1936 & Moyero River Formation, Russia & Vikhorevian-Volginian & Dw2-Dw3 \\
\hline Tolmachovia corbetti Pojeta \& Gilbert-Tomlinson, 1977 & Cabbage Tree Formation, Australia & Lancefieldian & $\operatorname{Tr} 3$ \\
\hline Tolmachovia crassa Thoral, 1935 & La Maurerie Formation, France & 'Arenigian' & $\mathrm{F} 11-\mathrm{Fl} 2$ \\
\hline Tolmachovia landeyranensis Babin et al., 1982 & Landeyran Formation, France & 'Arenigian' & $\mathrm{Fl2}-\mathrm{Fl3}$ \\
\hline Tolmachovia sp. sensu Babin et al., 1982 & Landeyran Formation, France & 'Arenigian' & $\mathrm{Fl} 2-\mathrm{Fl3}$ \\
\hline Tolmachovia spp., see Gutierrez-Marco (1997), Sá (2008) & Spain, Portugal & Oretanian & Dw2 \\
\hline Tolmachovia sp. in Pojeta \& Runnegar (1976) (emended here) & ?Moyero River Formation, Russia & Vikhorevian-Volginian & Dw2-Dw3 \\
\hline Tolmachovia sp. sensu Sánchez (1998) & San Juan Formation, Argentina & Oretanian & Dw2 \\
\hline Tolmachovia sublirata sp. nov. & Haljala erratics & Haljala & $\mathrm{Sa} 2$ \\
\hline
\end{tabular}

Etymology. - From Latin Sub meaning under and Liratus meaning lined, pertaining to the fine subordinate radial ornamentation.

Diagnosis. - A small species of Tolmachovia with fine radial ornamentation between the pronounced, upturned lamellar ribs on larger part of conch.

Description. - Shell small, length $9 \mathrm{~mm}$ (estimated), height $6.5 \mathrm{~mm}$ (estimated), width $4.2 \mathrm{~mm}$. Shell posterior to vertical axis unknown (Fig. 4A). Body broadly rounded with max width at periphery halfway along the vertical axis, tapering ventrally while gently rounded dorsally (Fig. 4D). Protoconch (internal cast protruding through shell) narrowly conical, pointed, with tip slightly curved anteriorly. Shell along dorsal axis slopes gently down anteriorly and posteriorly from the umbo with thin, sharp hinge line (Fig. 4B). Snout thin ( $1 \mathrm{~mm}$ wide in dorsal view) and crest-like. Preserved ventral margin of snout and body suggest broadly arcuate ventral margin. Anterior and ventral gapes slit-like and continuous, with fine denticles developed opposite each other along the ventral commissural margins (Fig. 4E). Ornamentation consist of densely spaced comarginal lamellar ribs, 5-6 lamellae per $\mathrm{mm}$ (measured along the vertical axis), curving slightly upward. At the lower part of the shell, about $1 \mathrm{~mm}$ from the ventral margin in a $c a$ $1 \mathrm{~mm}$ broad band on both sides of the conch the comarginal lamella are thinner and more densely spaced (Fig. 4A, D). Sub-ordinate, regularly spaced radial lirae are developed in the spaces between the lamellae, discernible at least on the main part of the body above the band of finer lamellae (Fig. 4A, C). Interior of shell unknown.

Remarks. - The specimen described here is the stratigraphically youngest species of Tolmachovia and is smaller than other species of Tolmachovia that usually reach more than
$10 \mathrm{~mm}$ in length and $22 \mathrm{~mm}$ in the case of $T$. andina; it may represent a juvenile exemplar. It is also unique in having subordinate radial ornamentation in-between the growth lamellae. Finer comarginal lirae were observed by Gutiérrez-Marco (1997) in-between the lamellae in T. babini, but radial ornamentation seems to be lacking in all of the taxa from Portugal and Spain (Gutiérrez-Marco \& Aceñolaza 1992, Gutiérrez-Marco 1997). The posterior third of Tolmachovia landeyranensis has marked radial ornamentation of nearly the same expression as the comarginal ribs (Babin et al. 1982). In this respect the thin and numerous comarginal lines in the type species $T$. concentrica, the ribs and radial ornament in $T$. landeyranensis and the strong lamellar ribs in the Iberian and Argentinian species are very different expression of the shell ornamentation and shows that this character is widely variable. With the pronounced, upturned lamellar ribs Tolmachevia sublirata from the Netherlands is closer to the Argentinean and Iberian forms.

\section{Genus Beukeria gen. nov.}

Type species. - Beukeria plicata sp. nov., by original designation herein and monotypy. From the Haljala group erratics (Haljala Stage) in the border area between the Netherlands and Germany.

Etymology. - Named after Jaap Beuker, a well-known archaeologist and former head curator of the Drents $\mathrm{Mu}-$ seum, Assen, (the Netherlands), who collected specimen RGM.1332179 in 1976 and presented it to Rhebergen in 1998. The gender is feminine.

Diagnosis. - An ischyriniid rostroconchs with elongated conch, thick pegmas, posterior pegma shorter, posterior shell long and tapering, ornamentation of comarginal ribs, plicate shell posterior to vertical axis with 7 prominent 


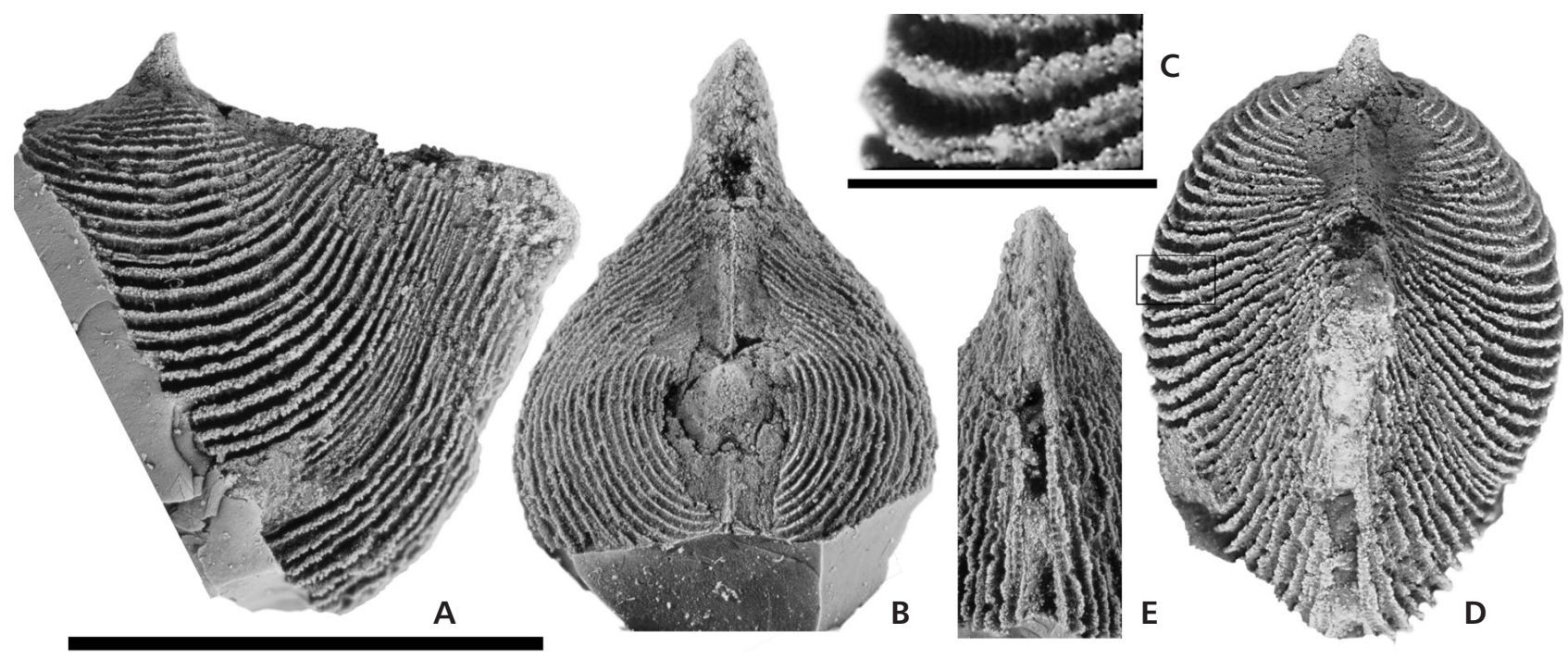

Figure 4. Tolmachovia sublirata sp. nov. from the Haljala group erratics (Haljala Stage) at Zwolle, the Netherlands. • A-E-RGM.1332175, silicon cast in right lateral, dorsal, detail of lamellae, section of ventral orifice and anterior views respectively. The black square in Fig. D shows the enlarged portion of the lamellar ribs in Fig. C. Scale bar for A, B, E, D = $0.5 \mathrm{~cm}$, scale bar for C $=0.1 \mathrm{~mm}$.

radial folds followed by flared primary carina that leads to a marginal sinus.

Remarks. - Beukeria plicata gen. nov. sp. nov. shows a unique combination of ischyriniid morphology such as two pegmas and anterior and posterior median musculature, while at the same time having an elongated body and a prominent primary carina suggesting similarity with certain members of the Technophoridae. Nevertheless, Beukeria is placed with the ischyriniids as two pegmas is one of the synapomorphic characters for the group (Wagner 1997). The second synapomorphy is the reduced posterior (i.e. the short rostral area) which is elongated in Beukeria and suggests a more basal position within the ischyriniids.

In Ischyrinia a primary carina is missing, possibly lost within the lineage, and instead a sulcus defines the transition to the rostral area. Ventrolaterally a distinct sinus is developed on each side, essentially producing a trilobed ventral gape (Fig. 3C). A similar arrangement is found in Beukeria, where the posterior part of the primary carina is flared with a terminal sinus. This sinus is directed more posteriorly, which essentially is a matter of the angle of the structure, but forms a trilobed arrangement with the posterior gape similar to that in Ischyrinia.

Technophorus sharpei (Perner, 1903) from the Bohdalec Formation (Katian) of the Czech Republic and a few similar rostroconchs (see clade in Wagner 1997, fig. 4) have a resemblance with Beukeria in that they have a markedly elongated posterior part of the conchs with just one carina (the primary carina) that runs in a concave curve from the posterior of the umbilical body towards the rear and ending in a ventral sinus at the ventral margin. The carina in these species does not stand out from the conch like in Beukeria but although with less amplitude they create the same trilobed arrangement of the posterior gape. The late Cambrian Oepikila Runnegar \& Pojeta, 1974 and the Ordovician Pauropegma Pojeta et al., 1977 from Australia show similar arrangements of the primary carina. Ventrally directed sinuses are also developed in species of Technophorus carrying two carinae, a primary at the rear and a secondary anterior to it (Wagner 1997). These were called gapes in Peel \& Horný (2004), comparing the carinae (called plications in Peel \& Horný 2004) with the lateral plication in the French Lower Ordovician helcionelloid mollusc Lamaureriella and pointing out both a functional and phylogenetic relationship. However, the analysis by Wagner (1997) suggested that the development of a primary carina in ischyriinids and technophoriid rostroconchs (as well as in derived conocardiids) is a convergent character. Although the structures may have served similar functions, e.g. a site for removal of pseudofaeces (Peel \& Horný 2004) they have little phylogenetic importance for the higher taxonomy.

Pauropegma Pojeta et al., 1977 from the Early Ordovician of Australia is similar to Beukeria in the large and triangular shape of the umbonal body and the development of the muscle insertions and growth band on the umbonal body. Pauropegma differs from Beukeria in having a shorter conch with an open anterior gape, a single primary carina, lacking posterior plications and less prominent pegmas (on internal mould).

Pleuropegma Pojeta et al., 1977 from the late Cambrian of Australia is similar to Beukeria in having 
4-5 plications (ribs in Pojeta et al. 1977, p. 25) developed on the posterior part of the shell. Pleuropegma is as well similar in the lack of an anterior gape and the erect posterior margin. It differs mainly from Beukeria in the shorter conch, lack of a prominent primary carina and in having a sulcus anterior to the ribs. Details of the internal mould, number of pegmas and external ornamentation in Pleuropegma is unknown.

\section{Beukeria plicata sp. nov.}

Figures 3, 5-9

Holotype. - RGM.1332176, a specimen preserved as an internal and external mould (Fig. 5). From the Haljala group erratics (Haljala Stage) at Wilsum, Germany. The specimen was collected by Rolf Smit who presented it to Rhebergen.

Other material. - Five other specimens, RGM.1332177 to 1332181 (Figs 6-8), all from the Haljala group erratics (Haljala Stage) at Zwolle, the Netherlands (RGM.1332177) and Wilsum, Germany (RGM.1332178 to 1332181 ).

Etymology. - From Latin Plicatus meaning folded/plicate, pertaining to the structures of the rostral area.

Diagnosis. - Same as for genus.

Description. - Steinkern: Largest specimen is the holotype; $13 \mathrm{~mm}$ in length, $8 \mathrm{~mm}$ in height, $3.8 \mathrm{~mm}$ in width (Fig. 5). Shell narrowly lenticular in cross-section, with ventral part made up of keel-like infill of commissure and dorsal part the rounded umbo (Figs 5B-E, 6C-F). Umbonal body broadly triangular in profile, delimited ventrolaterally by shallow arcuate groove, above which umbonal body expand so that it protrudes outside the margins of the shell (Figs 5E, 6F). Max width of umbonal body at base of pegmas. Height measured from umbo to groove below umbonal body is equal to width. Anterior surface of umbonal body convex with an angle of about $60^{\circ}$ to vertical axis, posterior surface flat with an angle of $\sim 50^{\circ}$ to vertical axis placing umbo anterior to centre of umbonal body. Both surfaces and lateral side with striation of median anterior and posterior muscle bands (Figs 5E, 6F). Latter also develop thicker band above striations, placed posteriorly on umbonal body and transversing it. Nearly all of umbonal body forward on anterior half of conch, taking up more than half the height of the conch measured along the vertical axis. Anterior part of conch limited, width along dorsal axis about half that of umbonal body. Conch posterior to umbonal body makes up nearly half the length along the dorsal axis, tapering backward to sharply truncated posterior margin. Pair of V-shaped plications (in posterior view) extends laterally from the posterior part of the conch, opening up to the rear (Figs 6C, F, 7A, B). They are nearly straight relative to the dorsal axis. Posterior part of conch along dorsal axis sloping gently backward, slightly upturned at posterior edge of posterior pegma or with narrow ridge, reflecting dorsal hinge line, extending to keel like posterior termination. Anterior margin curved in semi-circular arch into crest that nearly reaches height of umbo. Margin ventral to umbonal body nearly straight, continuing back and up at an angle of about $20^{\circ}$ relative to a flat base. Ventral margin developed as keel-like slit from crest to just posterior of umbonal body where an undulating slit is developed (Figs 5B, $\mathrm{D}, 6 \mathrm{C}-\mathrm{F})$, with 7 marked undulations at margin gradually decreasing in amplitude posteriorly and ending just under the V-shaped plications.

Outer she1l: Anterior part of shell with thin comarginal, slightly flared ribs, 5 per $\mathrm{mm}$ at mid-body (relative to vertical axis), being more densely spaced ventrally. Finer growth lines are developed in between the comarginal ribs (Fig. 5G). Shell posterior of to umbonal body with 7 radial, rounded plications, getting smaller and narrower posteriorly. Plications draped by comarginal ribs of same character as those on anterior part of the body (Figs 5F, H, J, 7B, D, $8,9)$. Angle relative to dorsal axis of anterior plication is $\sim 60^{\circ}$ and $\sim 20^{\circ}$ for the posterior plication. Primary carina developed posterior to last plication, raised and extended from the shell surface, the pair forming a V-shaped structure. Posterior of primary carina shell ornamentation diverge from overall pattern in one specimen (Figs 5I, 7B), as smooth area is followed by divaricate lirae and densely concentrated, slightly curved lirae at the posterior tip. Unknown if this is anomalous or typical for the taxon. At the rear the primary carina is open and together with the tear shaped opening of the posterior margin forms a trilobed posterior gape (Figs 5B, 7B). Ventral margin open with parallel serrations, anterior ventral margin lacking gape and essentially closed.

Remarks. - Specimen RGM.1332181 (Fig. 8) differs from the others assigned to Beukeria plicata in having stronger comarginal ribs and strong radial furrows (but see

Figure 5. Beukeria plicata gen. nov. sp. nov., holotype (RGM.1332176) from the Haljala group erratics (Haljala Stage) at Wilsum, Germany. - A-E - right lateral, anterior, posterior, ventral and dorsal views of steinkern. $\bullet \mathrm{F}-\mathrm{K}$ - silicon cast from external mould showing right side in lateral, oblique, ventral and posterior views (Figs F, H, J, K respectively), detail of ornamentation of mid body, and posterior part (Figs G, I respectively). Scale bar in Fig. A is $0.5 \mathrm{~cm}$ (same scale bar for Figs A - E, F, H, J), scale bars in Figs G, I, K = $0.1 \mathrm{~cm}$. 
Jan Ove R. Ebbestad et al. • Late Ordovician rostroconchs from fluvial erratics in northwestern Europe
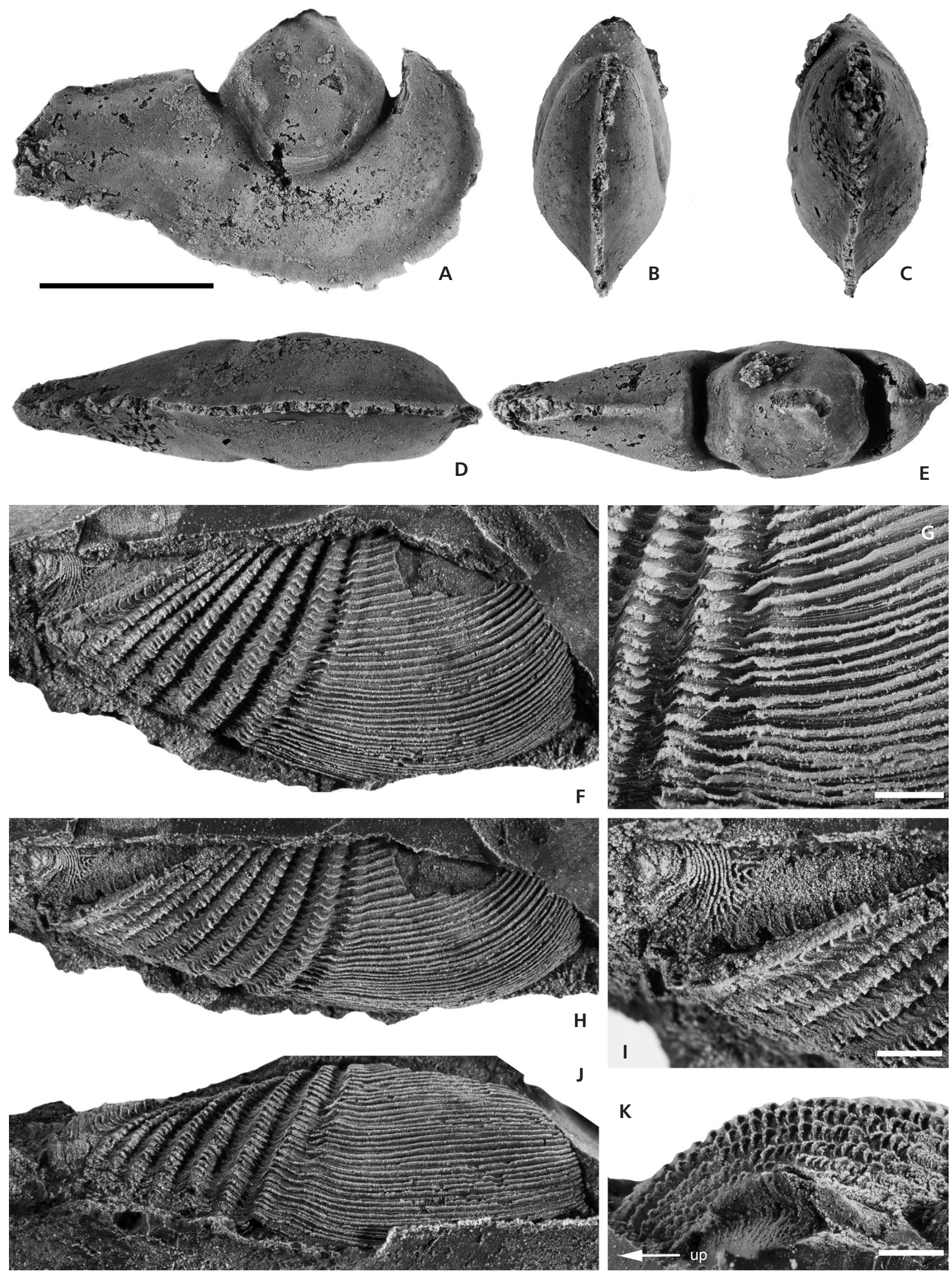

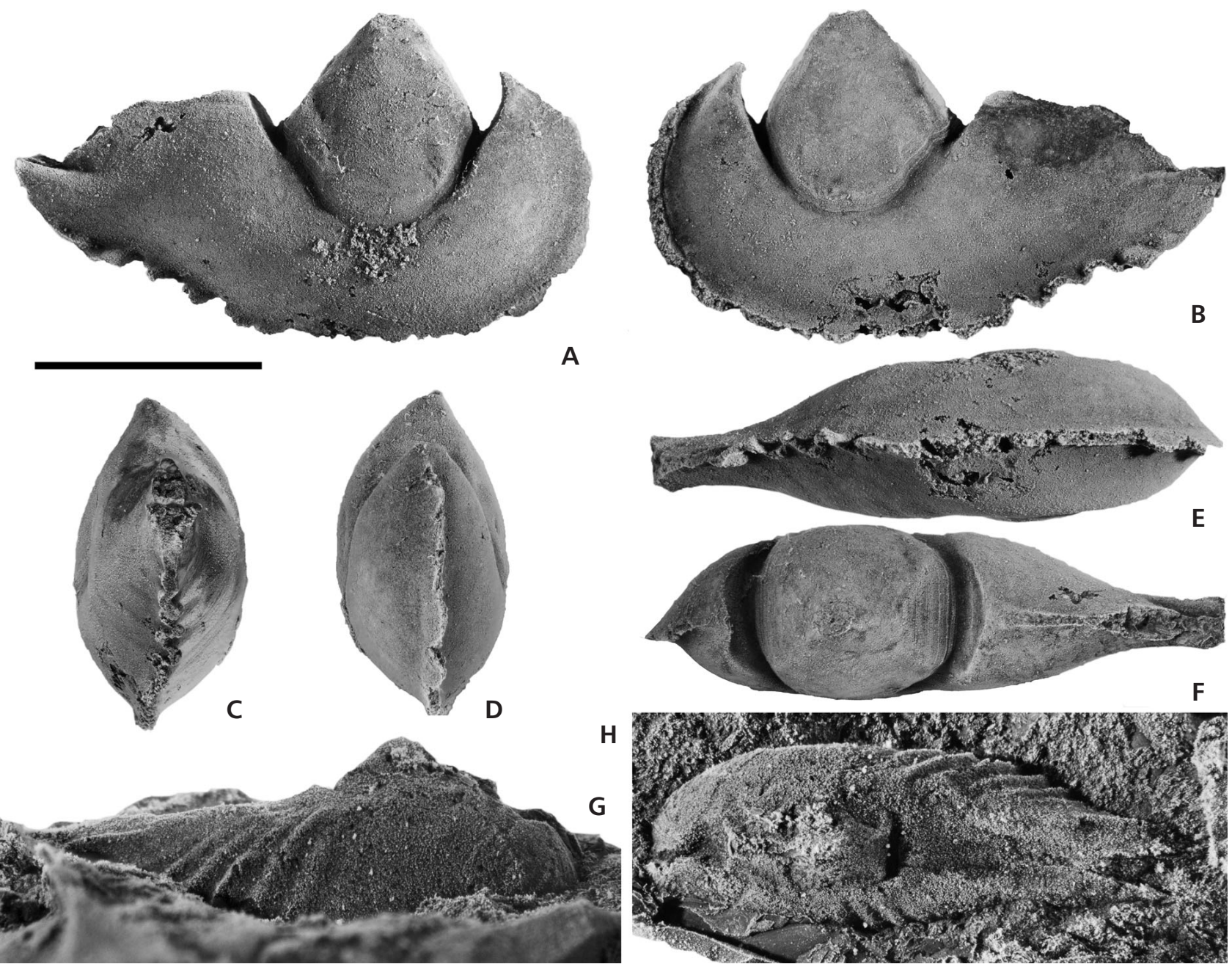

H

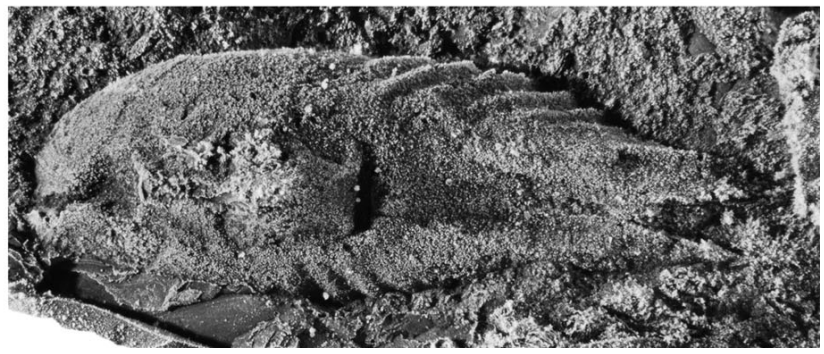

Figure 6. Beukeria plicata gen. nov. sp. nov., paratype (RGM.1332177) from the Haljala group erratics (Haljala Stage) at Zwolle, the Netherlands. - A-H - right lateral, left lateral, posterior, anterior, ventral and dorsal views of steinkern, and right lateral and dorsal views of silicon cast from external mould. Scale bar for all $=0.5 \mathrm{~cm}$.

Table 3. Alphabetic list of Ordovician species of Ischyrinia and their stratigraphical and geographical occurrences. Stage Slices follow Bergström et al. (2009).

\begin{tabular}{llll}
\hline Taxon & Occurrence & Local stages & Stage Slices \\
\hline Ischyrinia elongata Müldner, 1943 & Rollsteinkalk, Germany & Keila & Ka1 \\
Ischyrinia norvegica Soot-Ryen, 1960 & Furuberget Formation, Norway & Sandbian & Sa2 \\
Ischyrinia schmidti Teichert, 1930 & Korgessaare Formation, Estonia & Vormsi & Ka3 \\
Ischyrinia triangularis (Eichwald, 1842) & Pakri, Väo formations, Estonia & Kunda-Aseri & Dw2-Dw3 \\
Ischyrinia viator sp. nov. & Erratics, Germany and the Netherlands & Sandbian & Sa2 \\
Ischyrinia winchelli Billings, 1866 & Vaureal Formation, Canada & Katian & Ka4 \\
Ischyrinia sp. sensu Müldner (1943) & Rollsteinkalk, Germany & Keila & Hi1 \\
Ischyrinia sp. sensu Pojeta \& Runnegar (1976) & White head Formation, Canada & ?Gamachian & $?$ \\
Ischyrinia sp. sensu Pojeta \& Runnegar (1976) & Unknown, Wales & $?$ & \\
\hline
\end{tabular}

Fig. 7G, H). These are subordinate to the comarginal ribs and appear as punctuated lines in between the comarginal ribs. Furrows are developed on the anterior and middle body only, but none of these furrows reach the ventral margin and the posterior furrows are shorter than the anterior ones. Four plications are preserved on the posterior part of 

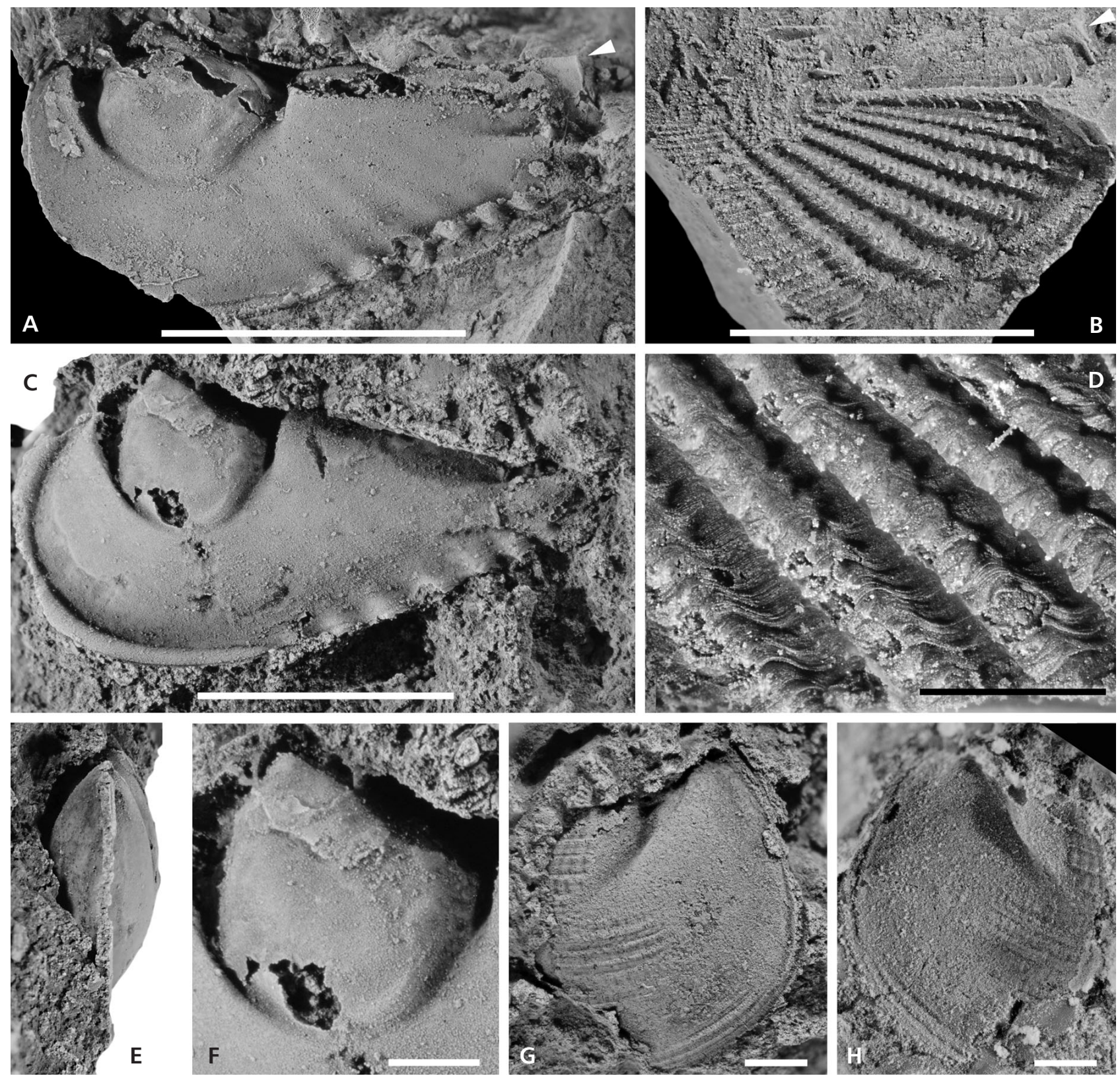

Figure 7. Beukeria plicata gen. nov. sp. nov., paratypes from the Haljala group erratics (Haljala Stage). A, B, D - RGM.1332178, left lateral view of steinkern, silicon cast of external mould of left side and detail of shell ornamentation respectively. White arrows in A and B points to top of posterior gape. Wilsum, Germany. - C, E, F - RGM.1332179, left lateral, anterior views and detail of umbonal body respectively. Wilsum, the Netherlands. - G, H - RGM.1332180, steinkern of anterior part with impressions of ornamentation and silicon cast of the steinkern respectively. Wilsum, Germany. Scale bars in Figs A-C, E $=0.5 \mathrm{~cm}$, scale bars in Figs D, F-G $=0.1 \mathrm{~cm}$.

the shell while the posteriormost part is missing. Besides the furrows and the strength of the comarginal ribs, the specimen conforms well to Beukeria plicata. The unique development of the ornamentation may reflect phentotypic variation, but the sample size and preservation do not allow assertion of this, and taxonomic uncertainty is given to the specimen by referring to it as Beukeria cf. plicata.

Reconstruction of external shell ornamentation of Beukeria plicata is shown in Fig. 9.

\section{Genus Ischyrinia Billings, 1866}

Type species. - By subsequent designation of Miller (1889) p. 483, Ischyrinia winchelli Billings, 1866, p. 16, fig. 4, from the upper Katian (Ka4) Vaureal Formation at Anticosti Island, Quebec, Canada.

Diagnosis. - (modified from Pojeta \& Runnegar 1976). Ribeirioid with two pegmas delimiting triangular umbonal 

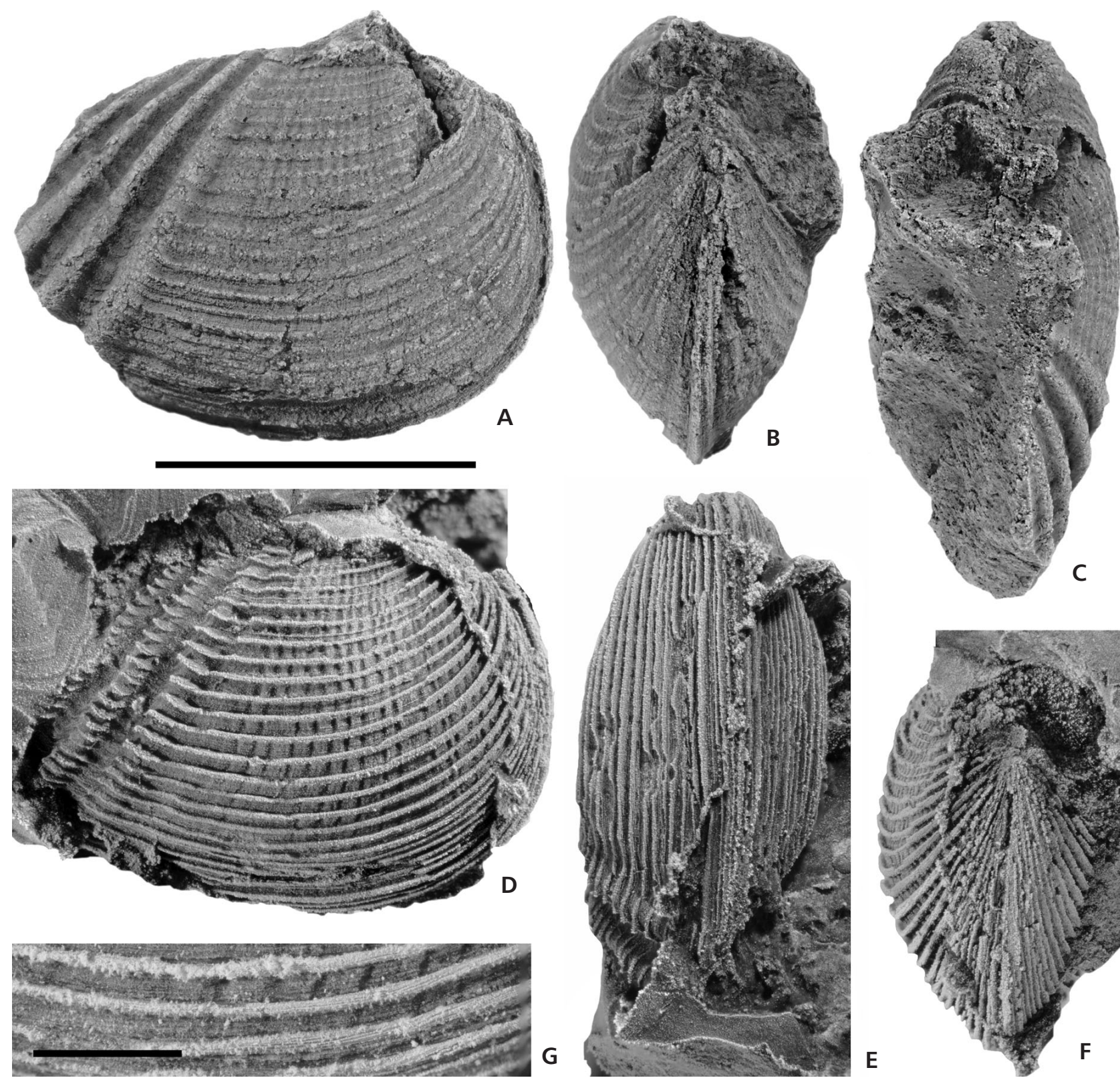

G

Figure 8. Beukeria cf. plicata, from the Haljala group erratics (Haljala Stage). A-G - RGM.1332181, right lateral, anterior and dorsal view of steinkern, and left, ventral, anterior views and detail of ornamentation of silicon cast respectively. Wilsum, Germany. Scale bar for all $=0.5 \mathrm{~cm}$.

body with two umbos, flanked anteriorly and posteriorly by pair of prongs on internal mould. Anterior and posterior median musculature insertions present with lateral continuations. Sulcus developed laterally on internal moulds in area of posterior pegma and associated with ventrolateral sinus, together demarking rostral area. Ornamentation with comarginal ribs and subordinated radial grooves progressively becoming more prominent posteriorly so that interareas form ribs.

Remarks. - With the two angled pegmas, the paired prongs, formation of a lateral sulcus and seemingly with a ventrolat- eral sinus associated with the sulcus (although this feature has not been confirmed in all species), Ischyrinia stands out as a very distinct genus. The sinus is a feature that is indicated in the illustrations by Pojeta \& Runnegar (1976, fig. 11o) but not further elaborated on. The anterior and posterior median musculature is similar to that seen in other ribeirioids like Ribeiria and Tolmachovia (see also Pojeta \& Runnegar 1976, fig. 3 and p. 35). Where ornamentation is known, the anterior part of the conch has predominantly comarginal lirae or ribs of various expressions, while radial grooves form posteriorly and progress in prominence and usually also width to eventually flank radial ribs. The 
Figure 9. Reconstruction of Beukeria plicata. Scale bar $=$ $0.5 \mathrm{~cm}$. Artwork by A.P. Gubanov.

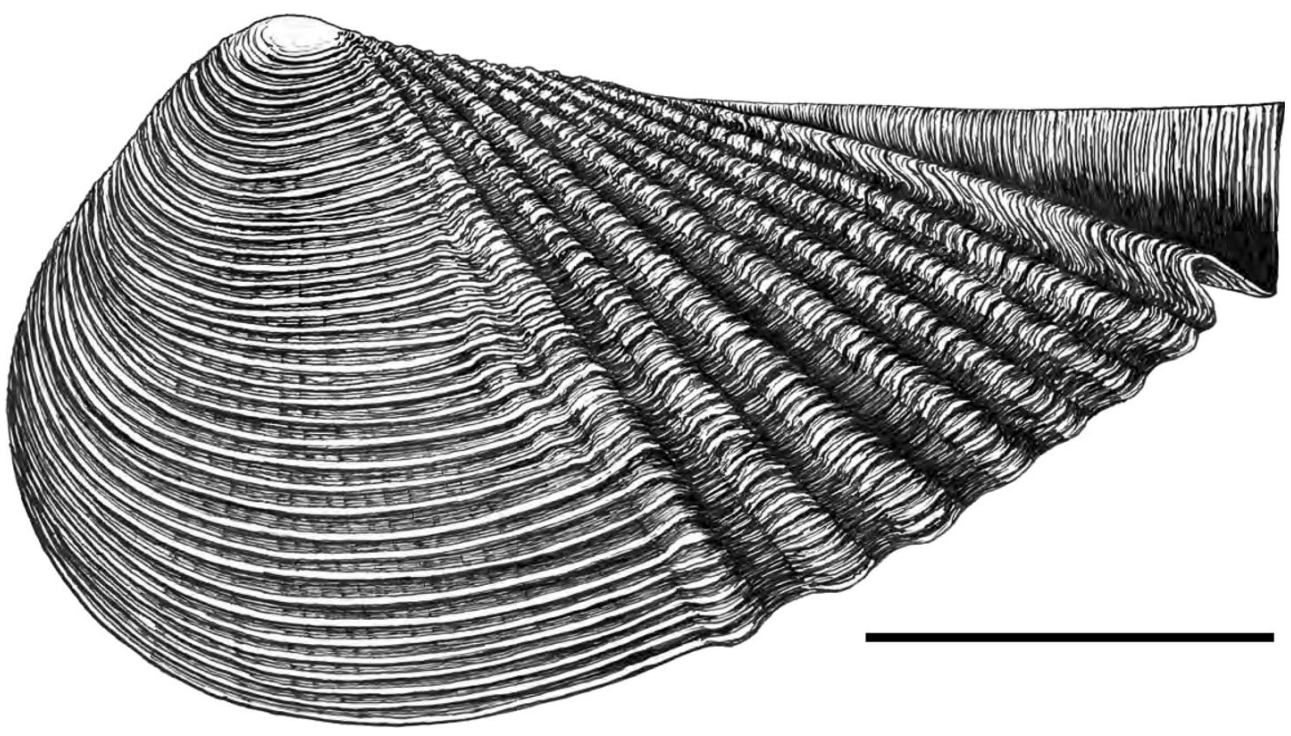

comarginal ornamentation is reduced to subordinate lirae basically only seen in the grooves.

Ischyrinia is mainly known from Baltica while the type species is Laurentian, from Anticosti Island in Canada (Tab. 3). The oldest species is $T$. triangularis from Estonia (Isakar 1997), while the youngest is Ischyrinia sp. most likely from the Hirnantian of Quebec, Canada (Tab. 3). The Russian species tentatively assigned to Ischyrinia by Pojeta \& Runnegar (1976, p.64, pl. 19, fig. 17) seems to lack prongs and is therefore transferred to Tolmachovia sublirata owing to the arcuate shape of the ventral margin. The Russian specimen seems to have marked radial ornamentation on the central body and on the posterior part of the conch, but prominent radial ornamentation is also seen in Tolmachovia landeyranensis from the Tremadocian of France (Babin et al. 1982) and in Tolmachovia sublirata described herein. Thus this feature alone does not exclude a placement of the Russian specimen to the genus.

Wagner (1997) showed that the morphology of Ischyrinia converge on that of conocardiids, with a primary carina, strong ornamentation and a well-defined rostral area. Pojeta \& Runnegar (1976) placed Pseudotechnophorus Kobayashi, 1933 in the Ischyrinidae while the analyses of Wagner (1997) lifted it out and placed it with the conocardiid clade.

\section{Ischyrinia viator sp. nov.}

Figures 3, 10-14

1994 Ischyrinia sp. - Rhebergen, p. 56.

Holotype. - RGM.1332182 (old coll. no. Rhebergen: $\mathrm{Z}$ 17.1a), from the Haljala group erratics (Haljala Stage) at Zwolle, the Netherlands (Fig. 10).
Other material. - Eight specimens (RGM.1332183 to 1332190), many preserved as steinkerns with corresponding external mould. All from the Haljala group erratics (Haljala Stage) at Zwolle, the Netherlands (RGM.1332184, 1332188) and Wilsum, Germany (RGM.1332183, 1332185-1332187, 1332189, 1332190).

Etymology. - From Latin Viator, meaning traveller. The name alludes to the long distance the rostroconchs described in this paper have moved.

Diagnosis. - An Ischyrinia with thick pegmas, anterior prongs smaller than stout posterior prongs that reach nearly to the umbos, prominent sulcus and ventrolateral sinus aligned with and at same angle as posterior pegma which together demark triangular rostral area (lateral view). Ornamentation consisting of fine ribs, supplanted posteriorly by thin radial grooves reaching at first only a short distance from the umbo, attaining full length posteriorly, becoming more dense and wider.

Description. - Steinkern: Holotype $16.4 \mathrm{~mm}$ long (Fig. 10). Largest steinkern from the erratic material is $11 \mathrm{~mm}$ in length and $7.5 \mathrm{~mm}$ in height (Fig. 12D). Width $2 /{ }_{3}$ of height and max width at peripherhy about $1 /{ }_{3}$ down the vertical axis. Body narrowly oval in cross section, tapering evenly ventrally and smoothly rounded dorsally to form two slightly incurved umbos (adaxially) (Figs 10G, H,11E, F). Peak of umbos placed to the side of the dorsal axis with a groove in between (Figs 10F, $11 \mathrm{H}, 12 \mathrm{H})$. Umbonal body broadly triangular in outline (lateral view), blunted dorsally, with curvature on anterior side slightly stronger so umbo placed slightly posterior to centre of umbonal body. Height of umbonal body about $1 / 2$ of width (measured from base of pegmas). 

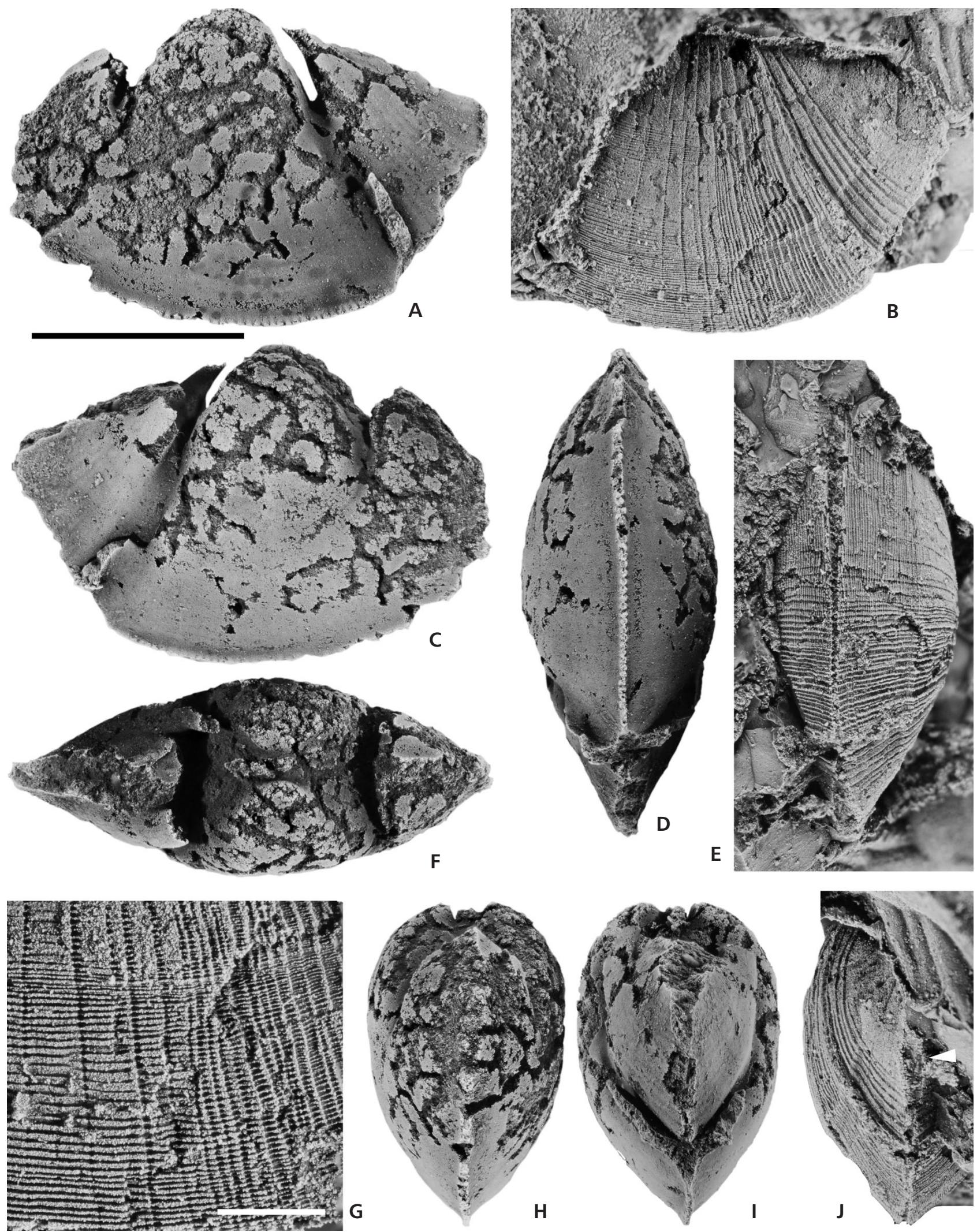

Figure 10. Ischyrina viator sp. nov., specimen RGM.1332182 from the Haljala group erratics (Haljala Stage) at Zwolle, the Netherlands. • A, C, D, F, H - left lateral, right lateral, ventral, dorsal, anterior and posterior views of steinkern. $\bullet \mathrm{B}, \mathrm{E}, \mathrm{G}, \mathrm{J}-$ silicon cast from external mould showing views of the left side, ventral, detail of shell and posterior of the specimen. Arrow in J points rostral orifice. Scale bar for all $=0.5 \mathrm{~mm}$, except for Fig. $\mathrm{G}$ where scale bar $=0.1 \mathrm{~cm}$. 

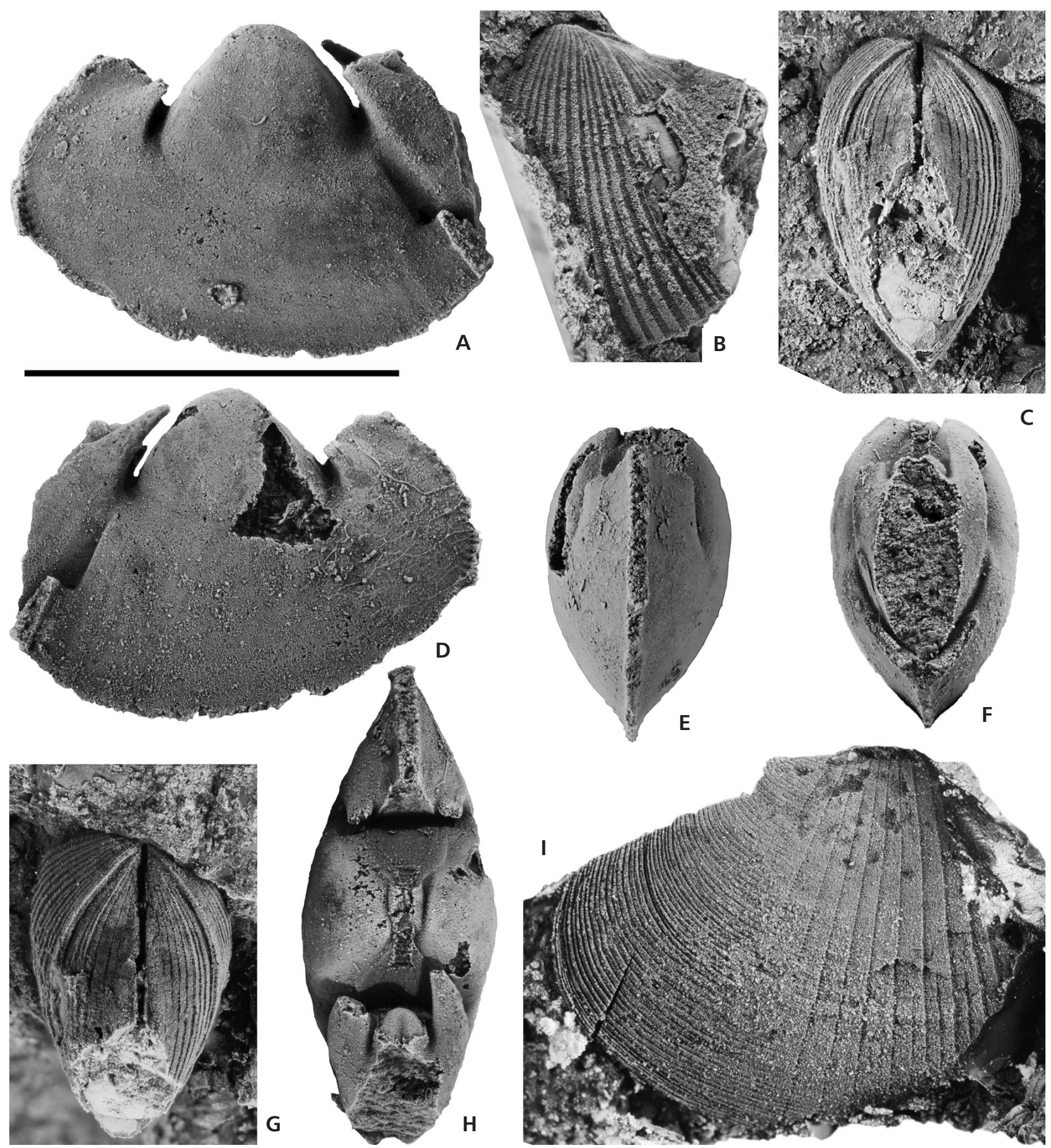

Figure 11. Ischyrina viator sp. nov., specimens from the Haljala group erratics (Haljala Stage). A-H - RGM.1332183, left lateral, right lateral, anterior, posterior and dorsal views of steinkern (Figs A, D-F, H respectively) and silicon cast of partial external mould showing left lateral, posterior and dorsal views (Figs B, C, G respectively). Wilsum, Germany. • I - RGM.1332184 silicon cast of external mould with details of ornamentation of central and anterior part of left side of shell. Zwolle, the Netherlands. Scale bar for all $=0.5 \mathrm{~cm}$.

Anterior and posterior sides of umbonal body form triangular areas (reflecting shape of pegmas). Anterior muscle scar narrow arcuate band near base of umbonal body, transversing body and reaching laterally approximately to vertical axis (Fig. 12C, D). Posterior median muscle scar touch or overlap slightly anterior muscle scar, but placed higher on the umbonal body and transversing it (Fig 12A, C, D). Shape of side muscle band irregular and 
thicker than the anterior muscle scar, with a short appendix protruding dorsally. Pegmas thick, straight, of about equal length, inclined about $50^{\circ}$ to vertical axis. Pair of prongs flanks the pegmas anterior to the anterior pegma and posterior to the posterior pegma (Fig. 12H). Prongs mirror curvature of the umbonal body. Posterior prongs much stouter than the anterior prongs, reaching almost to the height of the umbos (Fig. 12A, 13A). Anterior prongs reaching only half the height of the umbonal body. Anterior part of conch shorter than umbonal body, forming pointed crest that nearly reaches the height of the umbo. Body below umbonal body makes up slight more than half the total height measured along the vertical axis, separated from rostral area by distinct sulcus and sinus at ventrolateral margin (Figs 10A, C, 11A, D, 12A, G, 13A, $\mathrm{D}, \mathrm{E})$. Inclination of sulcus and sinus follow that of posterior umbonal margin. Sinus narrow, elongated dorsally, reaching $1 / 4$ of shell height. Rostral area narrower (transversely) than rest of conch forming in lateral view a triangular area between the prong, ventral margin and posterior tip (Figs 12G, 13E). Weak grooves represent impressions of external ornamentation. Ventral margin curving in semi-circle from crest to arcuate ventral margin of body and rostral area.

Outer shell: Ornamentation consists of fine comarginal ribs that are prominent on the anterior part of the shell and here lacking radial elements (Figs 10A, G, 11B, I, 13C, $\mathrm{G}, 14)$. Posterior to the (underlying) anterior prongs thin, widely based radial grooves appear, the anteriormost not reaching the ventral margin. Posterior to the vertical axis the grooves become more frequent and broaden, flanking either narrow or broad, flat ribs with grows now the corresponding narrow or broad interspaces. Comarginal ribs visible in interspaces but subordinate (Fig. 10G). Four to five widely spaced radial ribs are seen on anterior part of rostral area, ornamentation effaced on posterior part. No distinct primary carina is developed in the transition to the rostral area but ventrolateral sinus developed (Fig. 13C). Posterior gape elongated teardrop-shaped (broad end dorsally) leading into narrow closed rostral commissure which is seen as a narrow slit on the internal mould (Fig. 10J). Anterior to ventrolateral sinus the ventral gape is open, with asymmetric serration accentuated by the ribs, marked on internal mould as undulating slit (Fig. 10D, E). Anteriorly, where ribs not developed, ventral margin opens up anteriorly without a crenulated margin. Internal mould with narrow slit on ventral margin which extend to the crest but not widening to gape (Fig. 10E). Fine regularly spaced denticles are developed along entire ventral margin from anterior crest to posterior gape (Fig. 13F, H).

Remarks. - The specimens of Ischyrinia from erratics in the Netherlands and Germany are closely similar to Ischyrinia norvegica Soot-Ryen, 1960, known from the Sandbian (Sa2) Furuberget Formation in the Oslo Region, Norway. The holotype and syntypes of the Norwegian species (PMO 38267/1, PMO 38267/2, PMO 37861/1, 3 PMO $37861 / 2$, PMO $37861 / 3$ respectively) are almost twice the size of the specimens of $I$. viator and do not show external ornamentation. Two smaller specimens from the Ringerike district in the Oslo region, Norway (PMO 149.985 and PMO 150.042) appear similar to specimens of the type series (JORE personal observation) and are therefore considered conspecific. Of these two, PMO 149.985 preserves the ornamentation. The main differences between I. viator and I. norvegica are the position of the sulcus which in I. norvegica is more posterior to the posterior prong and the ventrolateral sinus is subparallel to the dorsal axis and not aligned with the sulcus as in I. viator. The rostral area is longer in I. norvegica and the conch is narrower with the maximum width a bit lower than in I. viator. The umbos in I. norvegica are also closer than in I. viator.

Ischyrinia viator $\mathrm{sp}$. nov. differs from the type species in the more elongated conch with a more prominent triangular rostral area (lateral view), an umbonal body that is wider relative to its width, thicker pegmas, a more rounded anterior margin, and the small anterior pair of prongs. Ischyrinia viator is nearly half the size of I. whincelli (16.4 $\mathrm{mm}$ vs $29 \mathrm{~mm}$ respectively) but with a slightly lower height:length ratio (0.68 vs 0.72$)$. Ischyrinia elongate from erratic in Germany is similar in overall shape to $I$. viator, although it is nearly twice as long as high (height:length ratio $=0.60$ ). Ischyrinia elongate also differs from $I$. viator in the shorter rostral area, the more prominent development of a primary carina, the development of a thinner pair of posterior prongs that reach to the height of the umbo and in the higher angle of the pegmas (data in Müldner 1943). It is also a larger species, attaining a length of $21 \mathrm{~mm}$ (Müldner 1943). The expression of the ornamentation seems to be similar in the

Figure 12. Ischyrina viator sp. nov., specimens from the Haljala group erratics (Haljala Stage). A-C - RGM.1332185, right lateral, posterior and dorsal view of partial steinkern with prominent muscle scars. Arrow in C points to inner part of anterior median muscle scar. Wilsum, Germany. - D, E - RGM.1332186, right lateral, and anterior view of large partial steinkern with prominent muscle scars. Note abnormal anterior prong. Wilsum, Germany. • F, G - RGM.1332187, left lateral and dorsal views of partial steinkern with rib grooves imprinted. Wilsum, Germany. $\bullet$ H-J - RGM.1332188, dorsal view of partial internal mould and silicon cast of its external mould showing left lateral and dorsal views respectively. Arrow in $\mathrm{H}$ points to raised margin of the dorsal hinge line. Zwolle, the Netherlands. Scale bar for all $=0.5 \mathrm{~cm}$. 

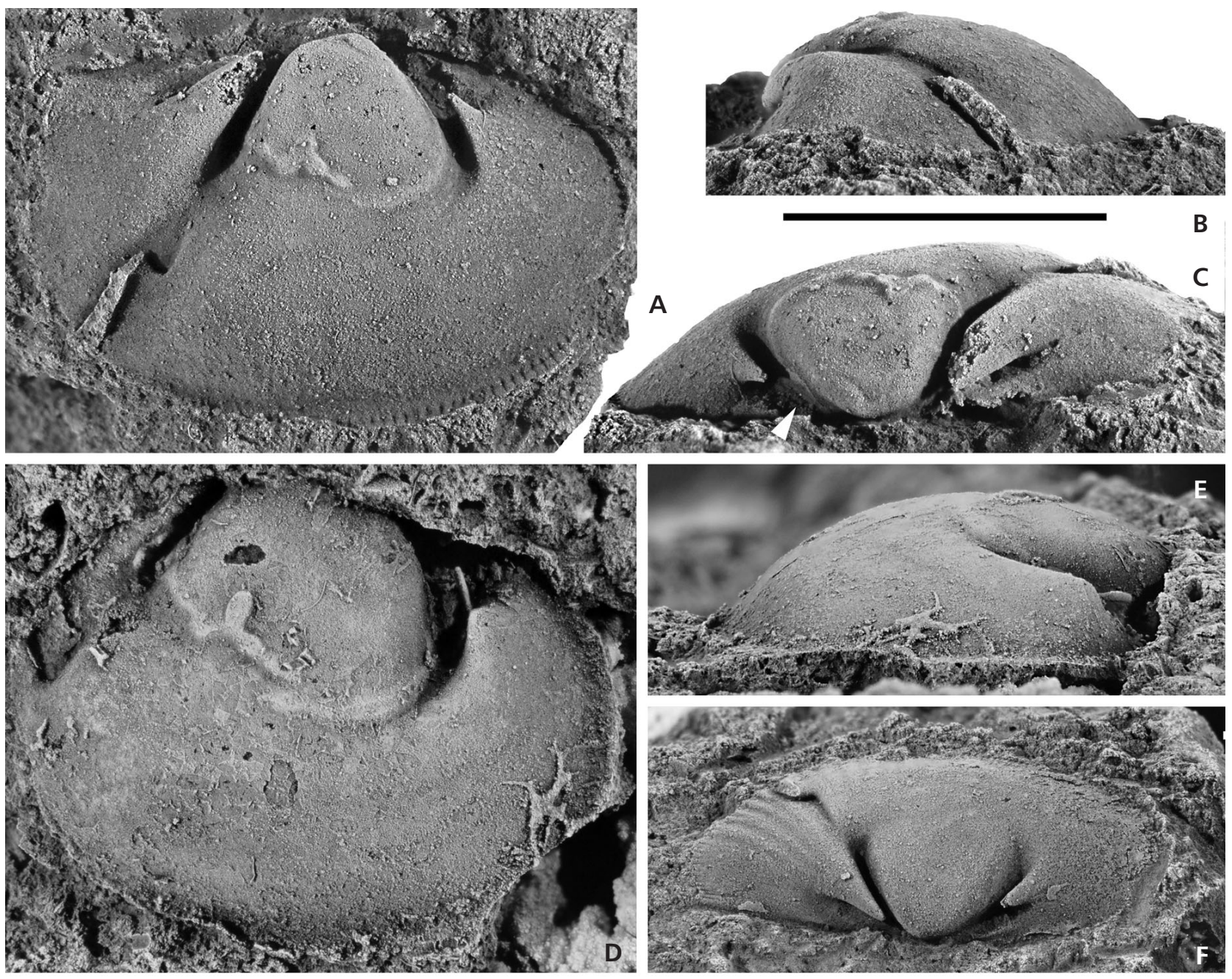

A
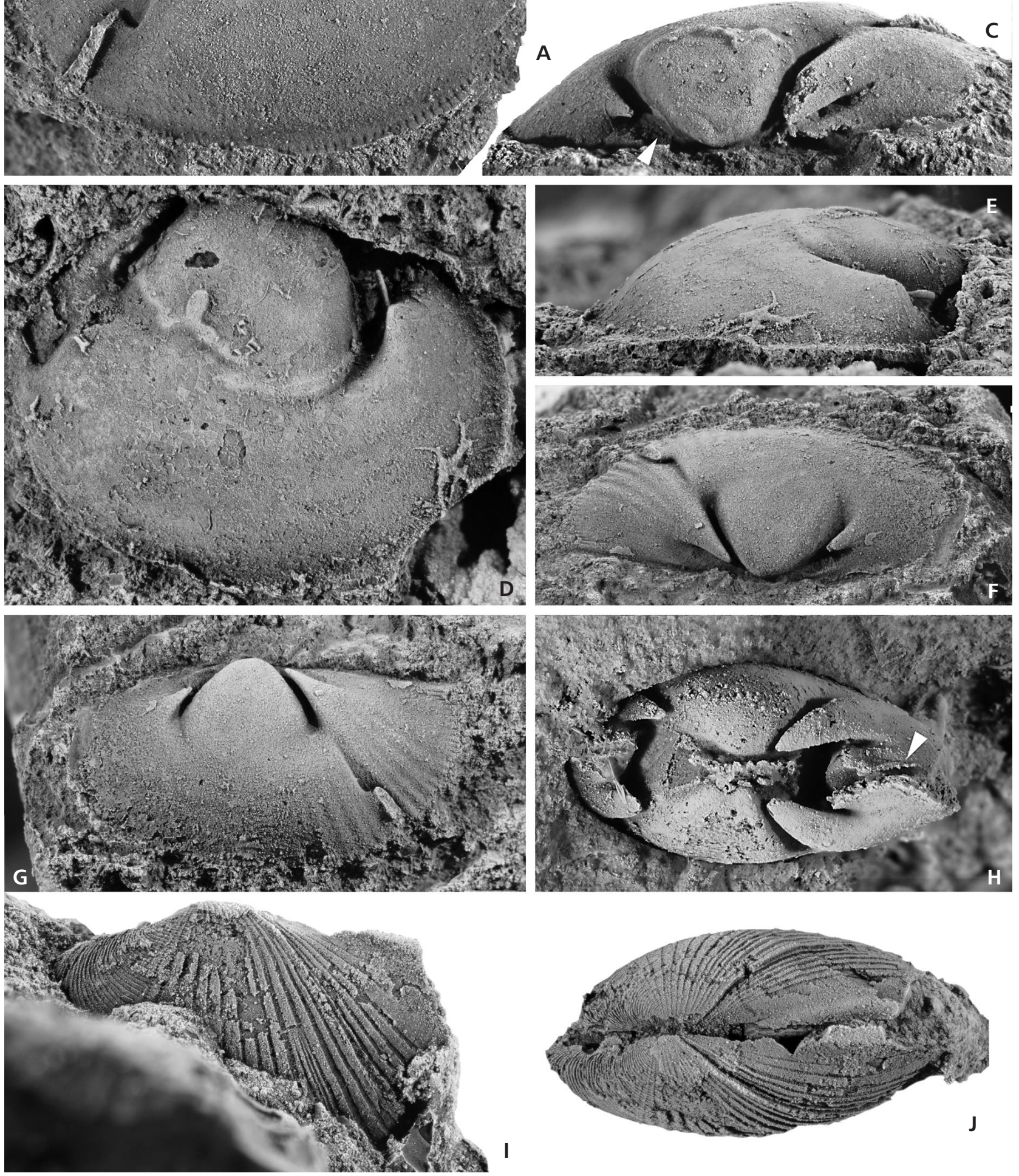
two species, with radial ornamentation in the posterior and absent in the anterior (Müldner 1943). Ischyrinia sp. from Wales (i.e. Pojeta \& Runnegar 1976, pl. 19, figs 5, 6) have ornamentation similar to that of $I$. viator but a larger anterior prong, narrower pegma and a subrectangular umbonal body.

\section{Order Conocardiida Neumayr, 1891}

Superfamily Hippocardioidea Pojeta \& Runnegar, 1976 Family Pseudobigaleaidae Hoare, Mapes \& Yancey, 2002 Subfamily Bitrigonocardiinae Rogalla \& Amler, 2006a

Remarks. - Hippocardiidae was erected by Pojeta \& Runnegar, 1976 for hood-bearing conocardiids, acknowledging that the large family probably was to embracive. Hoare et al. (2002) established the Carboniferous family Pseudobigaleaidae including some genera originally placed in the Hippocardiidae while Rogalla \& Amler (2006a, b, c) provided a thorough revision of both families. They showed that the Hippocardiidae always have radial ribs on the snout while the Pseudobigaleaidae lack these and vica versa the Pseudobigaleaidae have one or two sulci on the body while the Hippocardiidae lack these.

Rogalla \& Amler (2006a) further subdivided the Pseudobigaleaidae into four subfamilies of which the monotypic Bitrigonocardiinae Rogalla \& Amler, 2006a is of relevance here. The family was distinguished by the orthocline conch, presence of a primary carina with a single hood, a body furrow (Körperfurche = sulcus) separating the body from the snout, no radial ribs on the snout, and the rostral area occupying full height of the body. Taxa within the Pseudobigaleaidae with a combination of these were recognized as bitrigonocardiid (Rogalla \& Amler 2006a, p. 189). Rogalla \& Amler (2006a) pointed out that the synapomorphic orthocline conch distinguishes this subfamily within the Pseudobigaleaidae and that its relationship to the other subfamilies was unclear.

\section{Genus Bitrigonocardia Rogalla \& Amler, 2006a}

Type species. - By original designation, Pleurorhynchus dipterus var. rhomboideus Salter, 1851, pp. 175-176, pl. 8, fig. 6, from the Darriwilian (Dw3) Craighead-Limestone, Scotland.

Diagnosis. - (translated and modified from Rogalla \& Amler 2006a, p. 189). Conch bitrigonocardiform, snout triangular to nose-like, outline of the anterior gape teardrop-shaped (broad end dorsally), marginal denticles present, ventral margin of the snout slightly convex to diagonal. Ventral margin of the body straight or convex, diverging from dorsal axis, two carinae present on the body. Rostral area heart-shaped with rostral commissure, surface flat to strongly convex with prominent radial ornamentation, surrounded by distinct hood. Rostrum (when developed) at acute angle to the dorsal axis. Rostral clefts known.

Remarks. - The type species Bitrigonocardia diptera (Salter, 1851) is known from the Darriwilian (Dw3) Craighead Limestone in Scotland and the Hirnantian (Hi1) Kildare Limestone Formation of Ireland (Rogalla \& Amler 2006a), while the remaining taxa originally included in the genus are from the early to middle Silurian [i.e. Bitrigonocardia dorsata (Barrande, 1881), Bitrigonocardia elegantula (Billings, 1866) and B. reticulata (Krause, 1877)]. Amler \& Gummersbach (2015) re-surrected B. lindstroemi (Isberg, 1934) from the Upper Ordovician (Ka4) Boda limestone of Dalarna, Sweden which had been considered a junior synonym of $B$. elegantula from the Silurian (Aeronian-Telychian) of Anticosti Island, Canada, by Rogalla \& Amler (2006a). Isberg (1934) described a second species, Conocardium pygmaeum, from the Boda Limestone. Branson (1942) recognized the homonymy between Conocardium pygmaeum Hisinger, 1837 (as Cardium pygmaeum Hisinger, 1837) from the Silurian Visby Formation(?) on Gotland, Sweden and Conocardium pygmaeum Isberg, 1934 from the Ordovician Boda Limestone and replaced the latter name with Conocardium isbergia Branson, 1942. Pojeta \& Runnegar (1976) placed both C. isbergia Branson and C. lindstroemi Isberg in the new genus Bransonia and the Hisinger (1837) species with Hippocardia. Rogalla \& Amler (2007) pointed out that the whereabouts of the type material is unknown and treated Bransonia isbergia as nomen dubium. Unfortunately even the whereabouts of the type material of Bitrigonocardia lindstroemi is unknown (Amler \& Gummersbach 2015, p. 315).

Lindström in Angelin \& Lindström (1880) reported Pleurorynchus brachypleurus from Dalarna. Isberg (1934) placed it with Conocardium albeit doubting that it came from the Upper Ordovician Boda Limestone known from this area (Isberg 1934, Amler \& Rogalla 2013). The illustrations by Angelin \& Lindström (1880, pl. 13, figs 42-46) show a specimen that seems to have a bitrigonicardiid

Figure 13. Ischyrina viator sp. nov., specimens from the Haljala group erratics (Haljala Stage). Both from Wilsum, Germany. • A-D - RGM.1332189, right lateral, dorsal and detail of posterior parts of steinkern and silicon cast of right side of specimen (Fig. D) respectively. Arrow in $\mathrm{C}$ points to ventrolateral sinus. Wilsum, Germany. $\bullet$ E-H - RGM.1332190, left lateral view of partial steinkern (Fig. E), with silicon cast of internal mould and detail of ventral margin (Figs F, H respectively), and silicon cast of external mould of left side (Fig. G). Wilsum, Germany. Scale bars $=0.5$ cm, except for Figs D, H where scale bar is $0.1 \mathrm{~cm}$. 

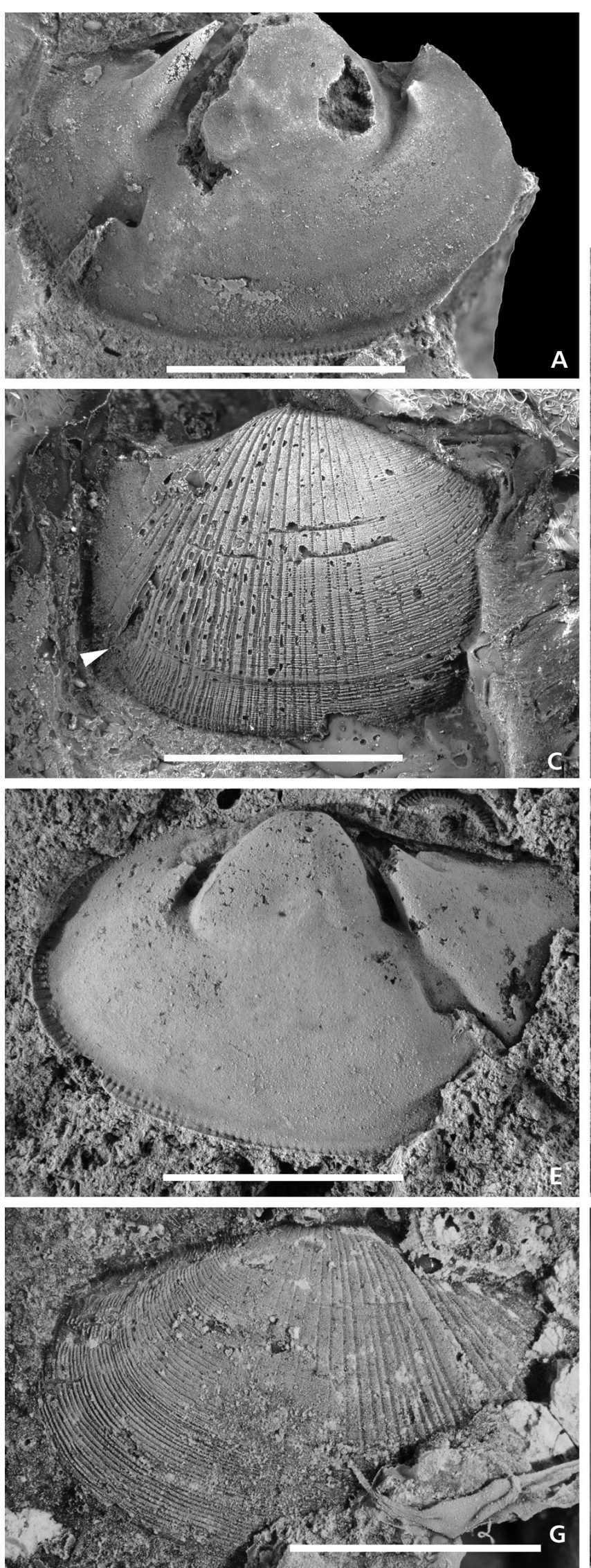
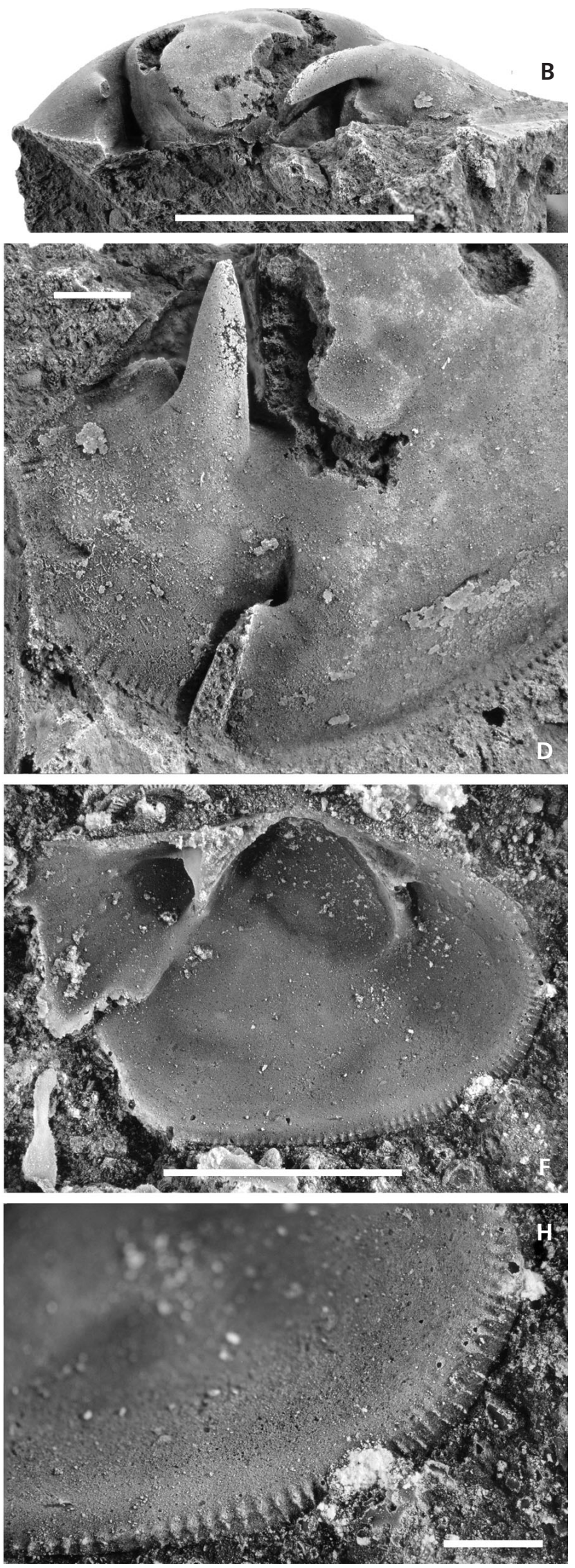


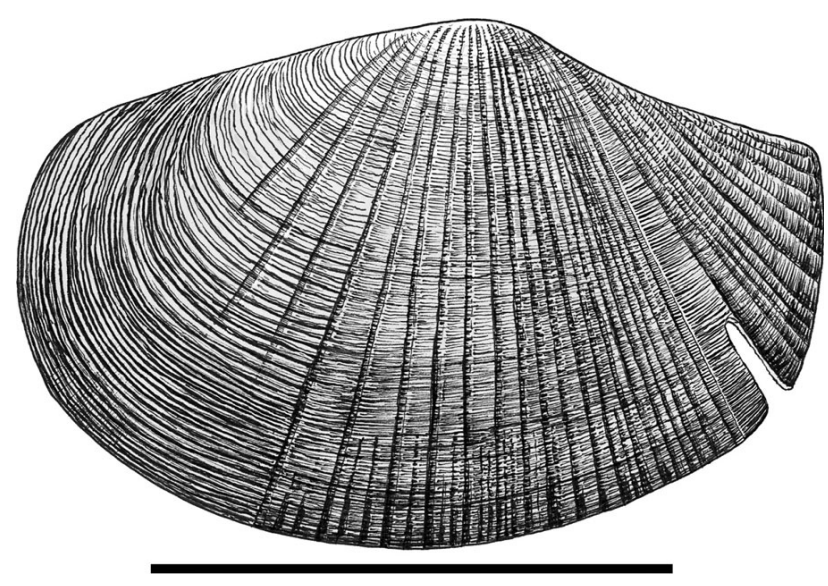

Figure 14. Reconstruction of Ischyrina viator $\mathrm{sp}$. nov. Scale bar = $0.5 \mathrm{~cm}$. Artwork by A.P. Gubanov.

shape. It is comparable to $B$. lindstroemi in size and the ribbed rostral area, but the whereabouts of the type specimen is also in this case unknown, precluding further comparison. The species is not included in the overview of rostroconch species recognized from the Ordovician of Baltica (Figure 2).

\section{Bitrigonocardia lindstroemi (Isberg, 1934)}

Figures 3, 15-21

1934 Conocardium lindströmii sp. nov.; Isberg, pp. 321, 322 , pl. 29, fig. 6a, b.

1966 Conocardium lindstroemii Isberg. - Branson, p. 79.

1976 Bransonia lindstromi (Isberg, 1934). - Pojeta \& Runnegar, p. 73.

1998 Hippocardia lindstroemi (Isberg, 1934). - Amler \& Bartholomäus, p. 394.

2006a Bitrigonocardia lindstroemi (Isberg, 1934). - Rogalla \& Amler, pp. 193, 194, fig. 10a not fig. 10b, c.

2015 Bitrigonocardia cf. reticulata (Krause, 1877). Amler \& Lohrengel, pp. 261-324, figs 2-4.

2015 Bitrigonocardia lindstroemi (Isberg, 1934). - Amler \& Gummersbach, pp. 311-323, figs 3-5.

Material - (erratic herein) RGM.1332191-RGM.1332205 from the Öjlemyr chert at Wielen in Germany (RGM. 1332191, 1332201, 1332202), Wilsum in Germany (RGM.1332192-1332200, 1332204) and Zwolle in the Netherlands (RGM.1332203, 1332205).

Description. - Steinkern: Conch bitrigonocardiid. Length of body and snout $2 / 3$ of height, width $1 / 3$ of height, largest uncompressed specimen being about $5 \mathrm{~mm}$ in height (Fig. 17D). Cross-section of conch narrowly heart shaped with largest width half-way along vertical axis (Fig. 16E, F). Snout nose-like, narrow, anterior gape teardrop-shaped (broad end dorsally), denticles not visible, ventral margin of snout weakly convex. Shell closed at ventral margin of body, being evenly convex and divergent. Angle $55^{\circ}$ relative to dorsal axis. Body commissure tightly sinuate with 5 oscillations, alternating ribs meeting medianally (Figs 16B, 17E, 18E). Primary carina prominent, slightly concave to flat, with broadest part being $1 / 10$ of height. Umbos do not meet dorsally at midline. Carina terminated and separated ventrally from body tube by shallow groove. Body tube circular with same width as primary carina, length slightly less than half of conch height (Fig. 18). Commissure seen as raised, nearly straight lines on both anterior and posterior side of body tube and fine, densely spaced lines develop on the tube normal to the commissure along its length (Fig. 18D-F). Rostral area pointed concave extending into long, slightly tapering rostrum being rounded in cross-section, angled dorsally at about $10^{\circ}$ relative to dorsal axis but slightly convex (Fig. 16A). Rostral area with rostrum makes up $1 / 4$ of total length. Rostral commissure tightly sinuate with 6 or 7 oscillations having less amplitude posteriorly (Fig. 16F). On anterior part of rostral area alternating ribs meet at the commissure, while posteriorly ribs are missing and commissure develops as thin line along the ventral of the rostrum (Figs 16F,18E). Ornamentation impressed on steinkern shows fine comarginal lirae on snout, sometimes with a faintly expressed and subordinate radial component (Figs 16D, 17A, C, 19E, G). At transition to body, narrow radial ribs develop more prominently, but expression and strength is variable. Close to primary carina narrow raised ribs are always developed. Comarginal ornamentation travels across ribs, being convex dorsally and continuing in similar fashion across the primary carina as pseudo-lunulae (Figs 16D, 17C, 19E, G). Initial part of rostral area with 6-7 flat-toped to slightly rounded, broad ribs interspaced with equally wide grooves (Figs 16F, 17A). Ribs fade posteriorly and replaced by fine comarginal lirae that are more regular and stronger than on snout.

Outer shell and hood: Two shell layers are discernible, labelled 1 (outer) and 2 (inner) in Fig. 17B. Inner shell layer mirrors ornamentation on internal moulds as it was impressed on the steinkerns (Fig. 21). Outer shell layer on snout and body coarsely reticulate with radial ribs dominating (Figs 17B, 19F). Suboval fenestra develops as a weathering feature. Ornamentation of rostral area similar to that of

Figure 15. Bitrigonocardia lindstroemi (Isberg, 1934) from the Öjlemyr chert (Pirgu). A, B - RGM.1332191, right lateral view of steinkern and silicon cast from external mould respectively. Wielen, Germany. - C - RGM.1332192, right lateral view of steinkern. Wilsum, Germany. 

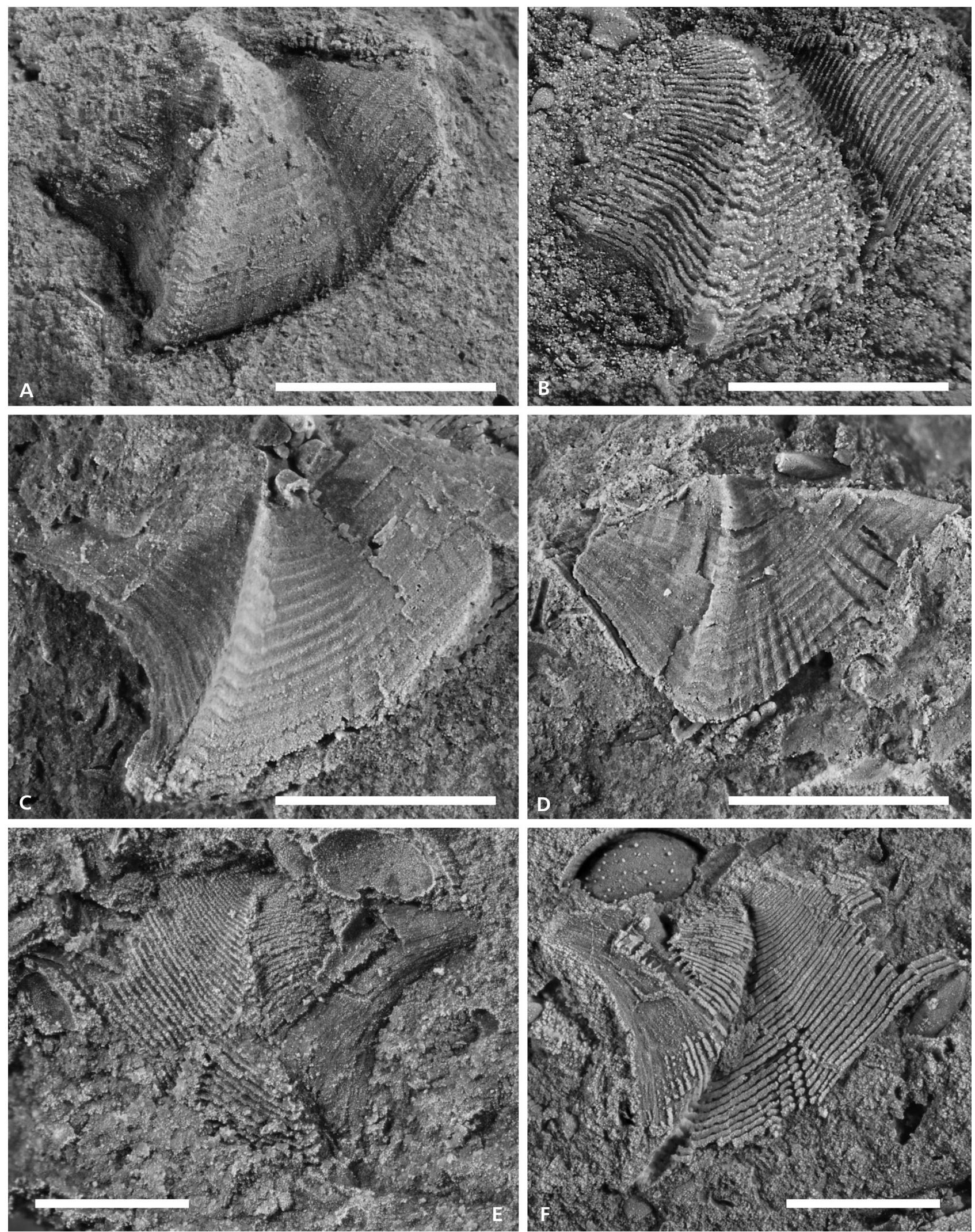

-D - RGM.1332193, right lateral view of steinkern. Wilsum, Germany. E, F-RGM.1332194, silicon cast of left lateral side, and external mould of left side with shell structure preserved. Wilsum, Germany. Scale bars for all $=0.1 \mathrm{~cm}$. 


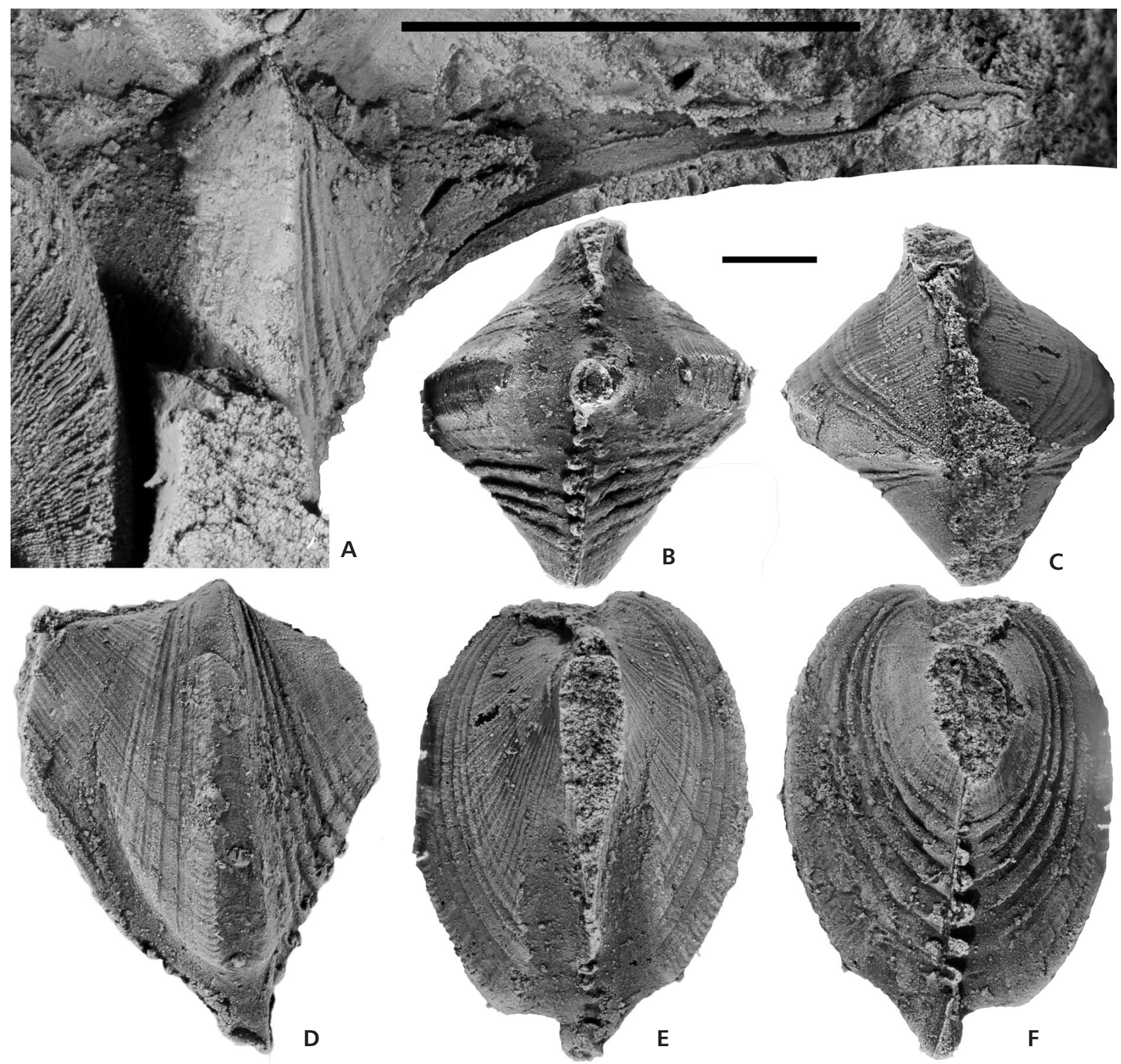

Figure 16. Bitrigonocardia lindstroemi (Isberg, 1934) from the Öjlemyr chert (Pirgu). A - RGM.1332195, left lateral view of specimen with rostrum preserved. Wilsum, Germany. • B-F - RGM.1332196, steinkern showing ventral dorsal, left lateral, anterior and posterior views respectively. See Fig. $17 \mathrm{H}$, I for silicon cast of external mould. Wilsum, Germany. Scale bar for all $=0.1 \mathrm{~cm}$.

snout and body but seemingly less coarsely reticulated and with more comarginal lirae posteriorly (Figs 17B, H, I, 18G, 19B). Hood concave, curving out and posteriorly like the brim of a sombrero (Fig. 20A, B). Maximum width of hood nearly equal to radius of conch, width being narrower at the dorsal end (Fig. 21B). Thickness of hood is reflected by the shape and width of the primary carina, being narrow dorsally and broader ventrally. Edge of hood rounded (Fig. 19C, G). Series of thin, radially distributed lamellae forms internal structure of hood, corresponding to fine outer radial ornamentation demarcated from the more clearly re- ticulate ornamentation of the conch (Fig. 19C). Transition on rostral surface usually marked by sharp line (Fig. 21).

Remarks. - Bitrigonocardia lindstroemi (Isberg) was originally described from two specimens from the Boda Limestone, Sweden, of which the designated holotype was figured (Isberg 1934, pl. 29, fig. 6). While the description by Isberg (1934) is difficult to use in a meaningful way, the illustration shows the holotype in great detail. Although the connection is circumstantial, Amler \& Gummersbach (2015) argued for a placement of a single specimen of theirs 

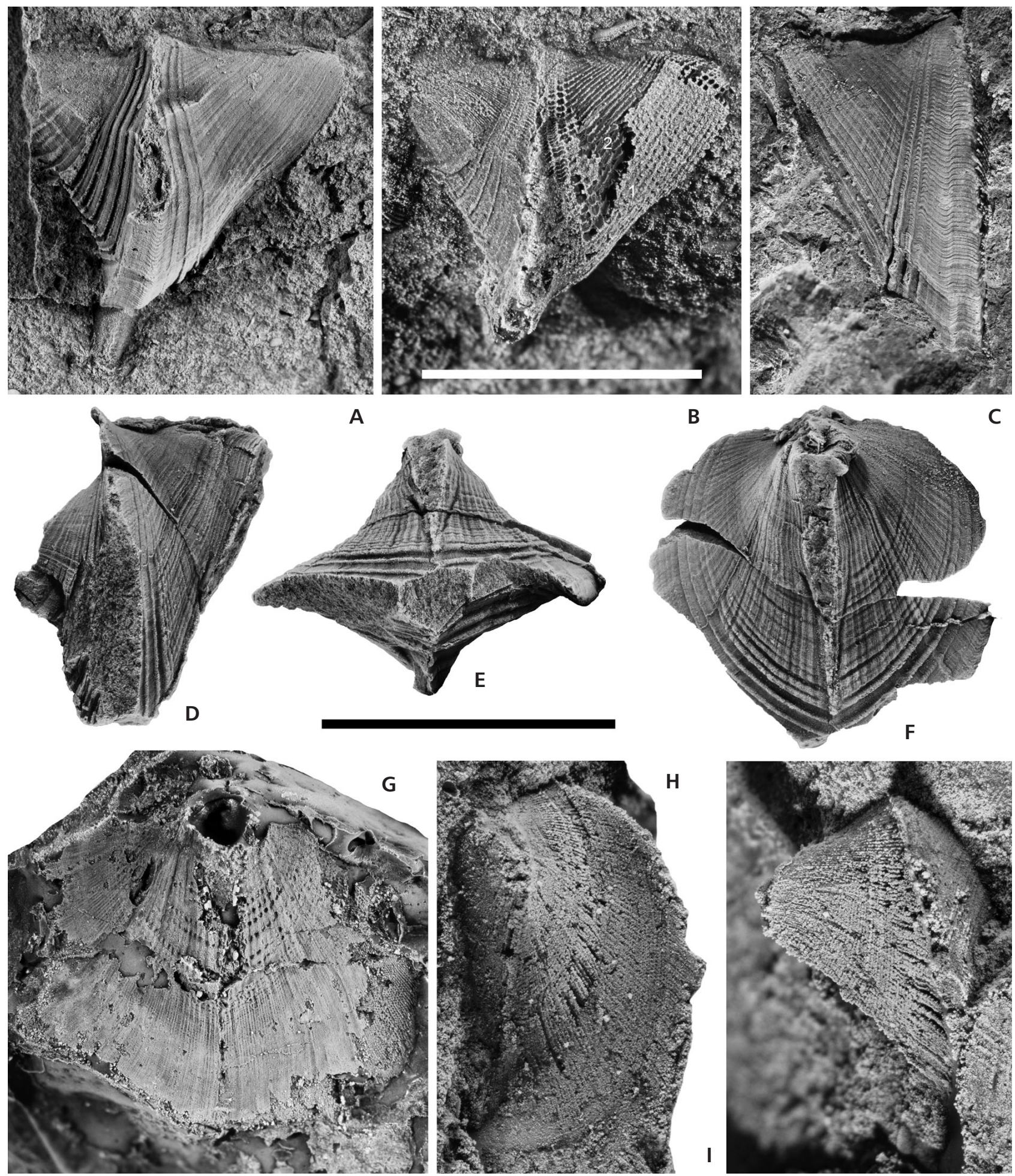

Figure 17. Bitrigonocardia lindstroemi (Isberg, 1934) from the Öjlemyr chert (Pirgu). A, B - RGM.1332197, internal mould and silicon cast of right side from external mould. The number s in Fig. 17B indicates outer (1) and inner (2) shell layers. Wilsum, Germany. $\bullet$ C RGM.1332198, left lateral side of steinkern. Wilsum, Germany. D-G - RGM.1332199, right lateral, ventral, and anterior views of steinkern, and silicon cast of external mould showing posterior view of the rostal area respectively. Wilsum, Germany. $\bullet$ H, I - RGM.1332196, silicon cast of external mould showing rostral area in posterior and right lateral views respectively. See Fig. 16B $-\mathrm{F}$ for corresponding internal mould. Wilsum, Germany. Scale bars for all $=0.5 \mathrm{~cm}$. 
Table 4. Alphabetic list of Ordovician species of Pojetaconcha and their stratigraphical and geographical occurrences. Stage Slices follow Bergström et al. (2009).

\begin{tabular}{|c|c|c|c|}
\hline Taxon & Occurrence & Local stages & Stage Slices \\
\hline Pojetaconcha alabamensis (Pojeta \& Runnegar, 1976) & Little Oak Formation, USA & Chazyan & Dw3-Sa1 \\
\hline Pojetaconcha beecheri (Raymond, 1905) & Chazy Limestone, USA & Chazyan & Dw3-Sa1 \\
\hline Pojetaconcha chapronierei (Pojeta et al., 1977) & Ninmaroo Formation, Australia & Lancefieldian & $\operatorname{Tr} 1$ \\
\hline Pojetaconcha costulata sp. nov. & Erratics, Germany & Pirgu & $\mathrm{Ka} 4$ \\
\hline Pojetaconcha cressmani (Pojeta \& Runnegar, 1976) & Lexington Limestone, USA & Chatfieldian & Ka1 \\
\hline Pojetaconcha limatula (Bradley, 1930) & Kimmswick Limestone, USA & Chatfieldian & Ka1 \\
\hline Pojetaconcha paquettensis (Wilson, 1956) & Mile End Formation, Canada & Chatfieldian & Ka1 \\
\hline Pojetaconcha aff. P. paquettensis (Wilson, 1956) & Holston Formation, USA & Turinian & $\mathrm{Sa} 2$ \\
\hline Pojetaconcha praepristis (Reed, 1952) & Killey Bridge Formation, Ireland & Rawtheyan & $\mathrm{Ka} 4$ \\
\hline Pojetaconcha townleyi (Pojeta \& Gilbert-Tomlinson, 1977) & Gordon Limestone, Australia & Eastonian & $\mathrm{Ka} 1-\mathrm{Ka} 2$ \\
\hline
\end{tabular}

from the Boda Limestone with Isbergs species. The fine preservation of the new specimen also made it possible to distinguish Bitrigonocardia lindstroemi (Isberg) from Bitrigonocardia elegantula (Billings) with which it had earlier been synonymized (Rogalla \& Amler 2006a).

Amler \& Lohrengel (2015) had earlier described a specimen from Boda Limestone erratics found in Germany and compared it to the Silurian Bitrigonocardia reticulata (Krause, 1877). Following Amler \& Gummersbach (2015, p. 319) it seems likely that this specimen should also be transferred to Bitrigonocardia lindstroemi although there are some differences in the number of ribs on the rostral area. This feature is, however, variable. The Boda Limestone specimens may have a well-preserved second shell layer but it is clear that the second shell layer is impressed on the steinkerns of the material described here from the Netherlands and Germany, causing variations in its expression and number of ribs. Only the sinuate commissure gives a reliable number of ribs, although the strength of the ribs may also vary especially towards either the anterior or posterior of the conch.

The new material presented here is placed with Bitrigonocardia lindstroemi (Isberg) as presently understood, based on comparison with the figured holotype and later associated specimens (Isberg 1934, Amler \& Gummersbach 2015, Amler \& Lohrengel 2015). Similarities include size, shape of the conch and hood and details of ornamentation. The width of the hood is slightly smaller in our material than in that of the specimen illustrated by Amler \& Gummersbach (2015). The surface of the primary carina seems flatter than that illustrated by Isberg (1934) and more similar to that in the specimen illustrated by Amler \& Lohrengel (2015).

Bitrigonocardia lindstroemi differs from the type species B. diptera (Salter) in having pointed concave rostral area instead of a pointed convex rostral area and a nose-like snout instead of the marked triangular snout of $B$. diptera. The primary carina in $B$. lindstroemi is broader and flatter than in $B$. diptera and the reticulate ornamentation on the snout is finer than in the type species. See Rogalla \& Amler (2006a) for illustrations of the type species.

The Silurian B. elegantula (Billings) from Anticosti Island in Canada, to which B. lindstroemi was earlier placed with, is poorly preserved and inadequately illustrated. Besides being younger, the Canadian species is proportionally wider relative to the height than $B$. lindstroemi and there are a greater number of radial ribs on the rostral area. The length of the snout and body seems shorter than in B. lindstroemi. Note that the order of the reproduction of the original illustrations in Rogalla \& Amler (2006a, fig. 10) is incorrect, as their fig. 10a is B. lindstroemi and not $B$. elegantula as stated in the figure caption.

Juvenile specimens. - Four tiny specimens measuring about 2 $\mathrm{mm}$ in preserved length are tentatively considered juvenile exemplars of Bitrigonocardia lindstroemi (Fig. 15). The ventral margin of the body is evenly convex and divergent in all specimens with an angle of $\mathrm{ca} 40-45^{\circ}$ relative to dorsal axis. At the umbos the primary carina is curved markedly posteriorly and the primary carina is angled forward from the ventral margin to the umbo, giving a more prosocline conch. One specimen (Fig. 15A, B) preserve both shell layers while a second specimen (Fig. 15E, F) preserves the outer shell layer.

Figure 18. Bitrigonocardia lindstroemi (Isberg, 1934) from the Öjlemyr chert (Pirgu). Specimens showing body tube. • A, B - RGM. 332200, anterior and posterior views respectively of flattened steinkern. See Fig. 20D, E for silicon cast of hood. Wilsum, Germany. • C, D - RGM.1332201, posterior view and detail respectively. Wielen, Germany. $\bullet$ E-G - RGM.1332202, anterior view of steinkern, detail of body tube and anterior view of silicon cast respectively. Wielen, Germany. Scale bars for all $=0.1 \mathrm{~cm}$. 

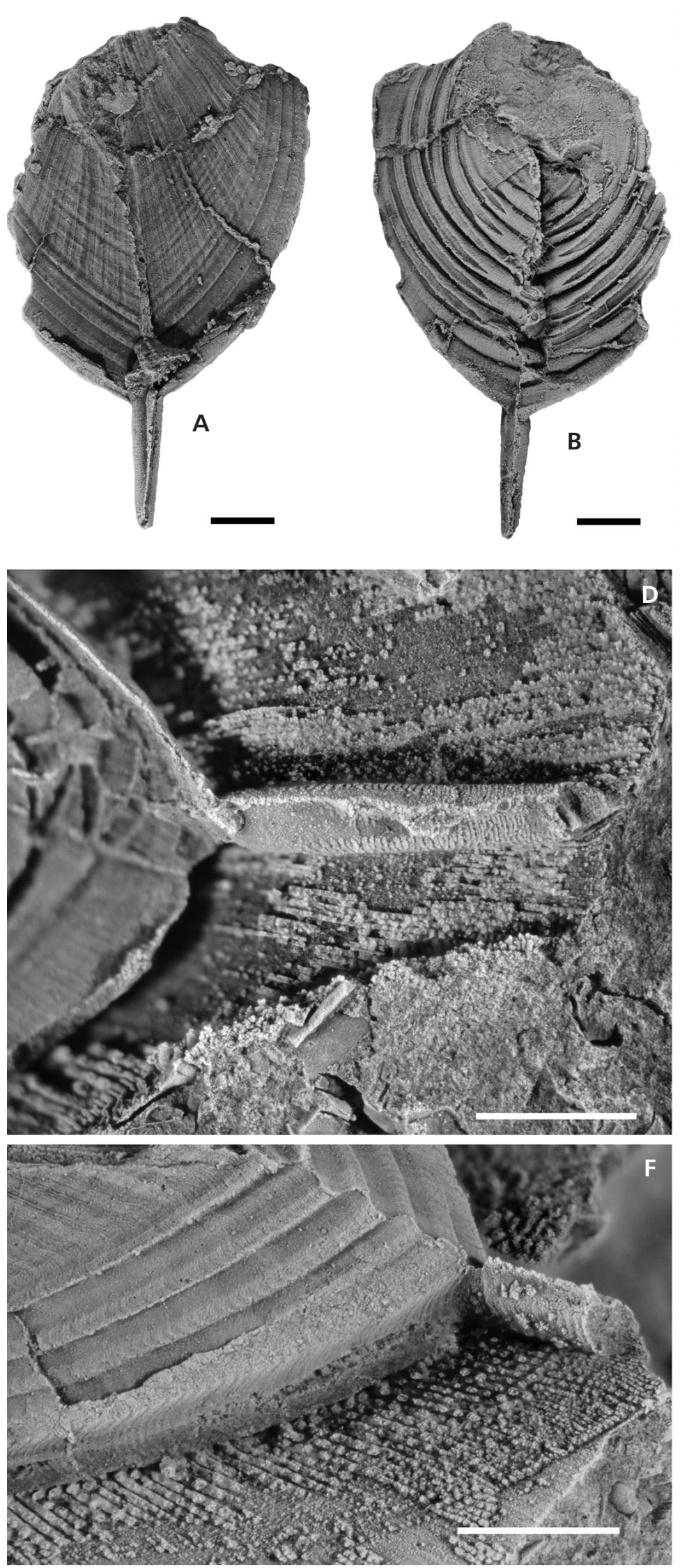
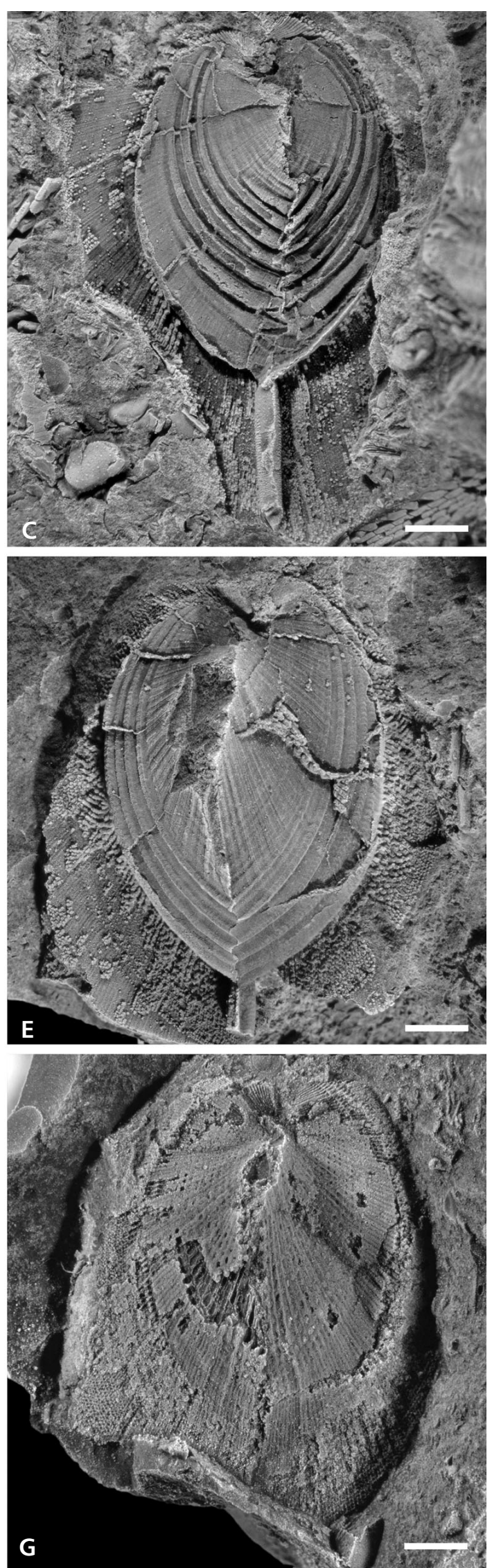

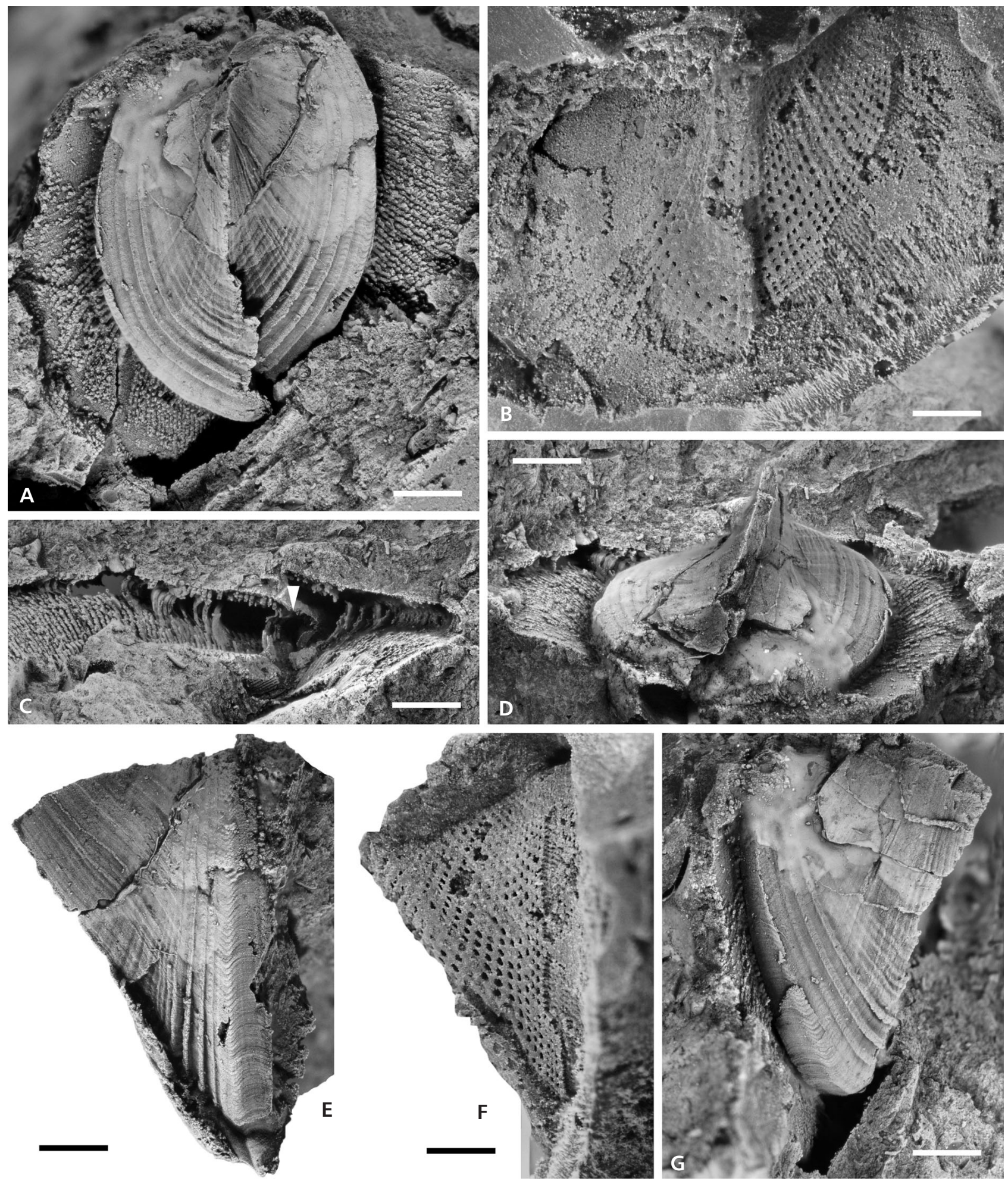

Figure 19. Bitrigonocardia lindstroemi (Isberg, 1934) from the Öjlemyr chert (Pirgu). Zwolle, the Netherlands. • A-G - RGM.1332203, anterior view of steinkern, silicon cast of external mould (anterior view), detail of hood intersection with body tube, dorsal oblique, left lateral views of steinkern and silicon cast of external mould, and right lateral views respectively. The steinkern can be removed from the hood-part allowing views of different aspects of the specimen. The arrow in $\mathrm{C}$ points to the hole after the centrally placed body tube. Lamellae are seen on each side of the central tube. Note the void in Fig. 19G left after the hood, which gives the thickness of the structure. Scale bars for all $=0.1 \mathrm{~cm}$. 

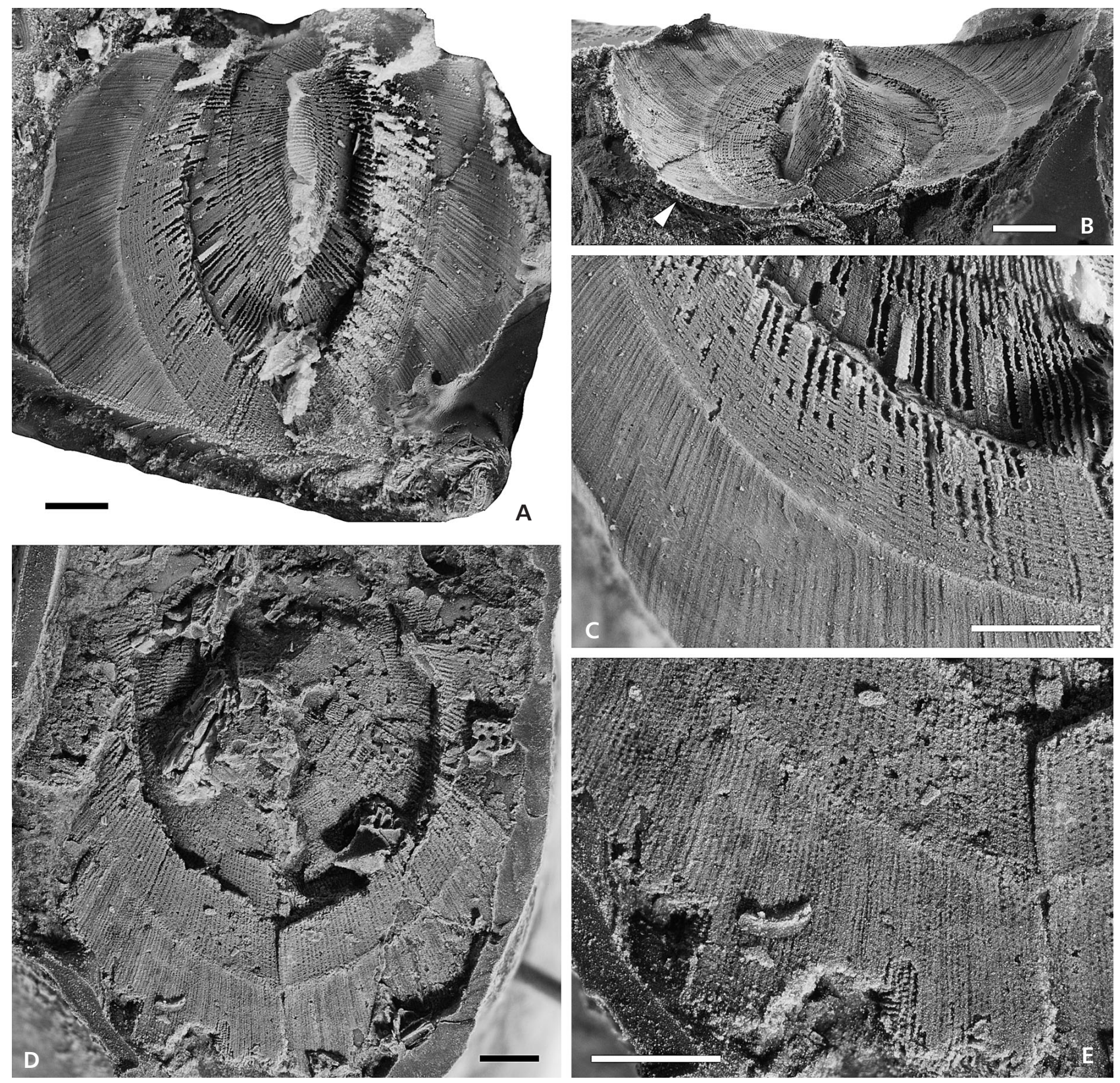

Figure 20. Bitrigonocardia lindstroemi (Isberg, 1934) from the Öjlemyr chert (Pirgu). A-C - RGM.1332204, silicon cast of external mould showing hood in posterior, dorsal oblique and detailed views. The arrow in B points to the dorsal edge of the hood. Wilsum, Germany. D, E - RGM.1332200, silicon cast of external mould showing hood in posterior view. See Fig. 18A, B for steinkern. Wilsum, Germany. Scale bars for all $=0.1 \mathrm{~cm}$.

In both the comarginal lirae are dominant with only a hint of radial structures on the body; radial structures are present on all steinkerns. The presence of a hood cannot be confirmed.

The major differences between these small specimens and the larger is the more prosocline conch $v s$ an orthocline conch, the near lack of radial structures and a reticulate ornamentation in the small specimens, and the lower angle of the vertical margin of the body which gives a longer snout section. The general shape of the conch and similarities in the ornamentation is what suggest that the small and large specimens belong with the same taxon. The specimen in Fig. $15 \mathrm{~F}$ shows a preservation of the outer shell layer on the body and snout that is similar to that of the larger specimens in the strong comarginal lirae of the inner layer and the way the outer layer is broken up in beads close to the primary carina (compare with Fig. 17B). The more prosocline conch in the small specimens is opposed to the diagnosis of Bitrigonocardia. However, most of the curvature is accomplished near the umbo which would suggest a straightening and adjustment of the anterior direction of 


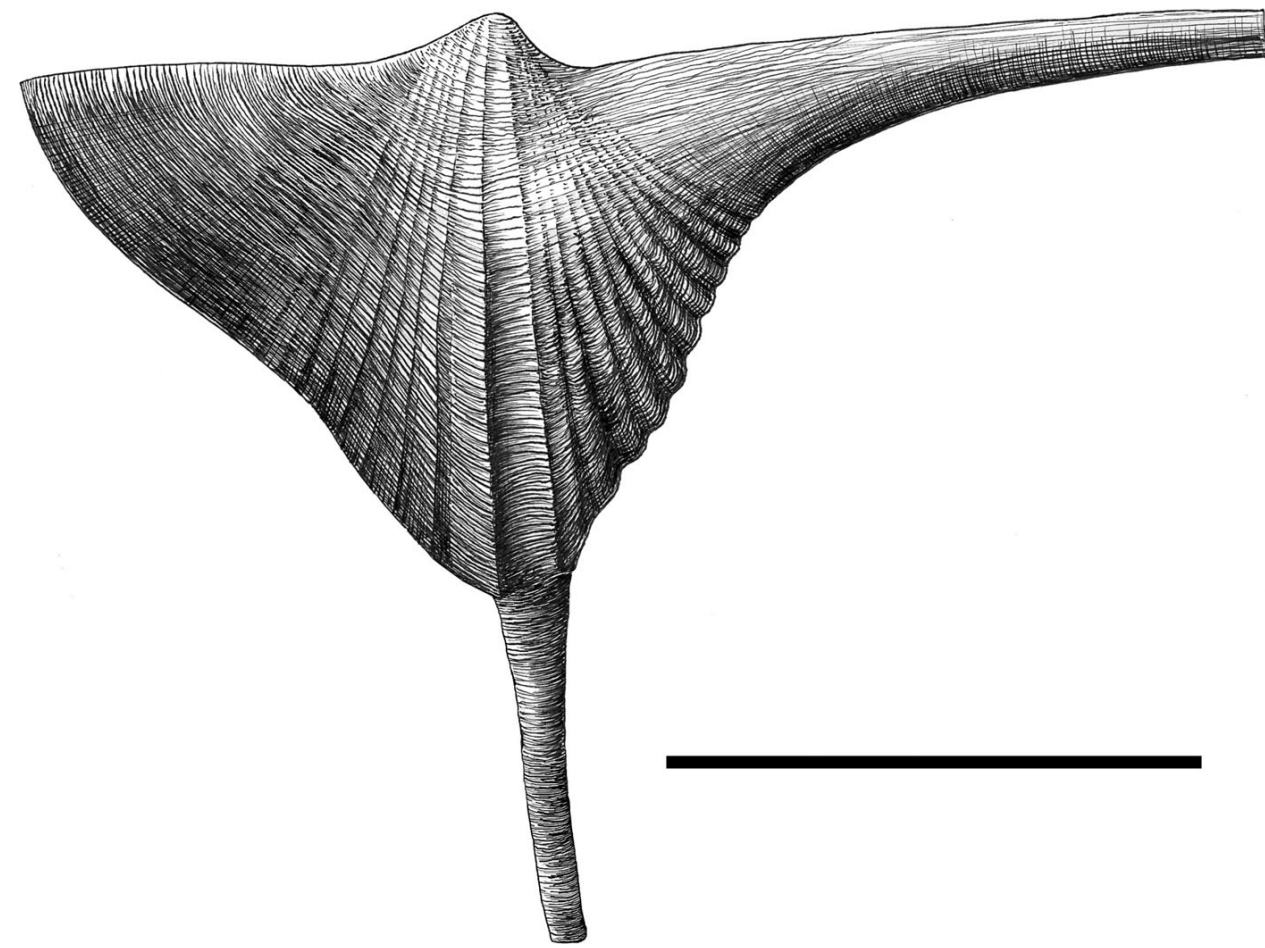

Figure 21. Reconstruction of $B i$ trigonocardia lindstroemi (Isberg, 1934). Scale bar $=0.5 \mathrm{~cm}$. Artwork by A.P. Gubanov.

the primary carina during growth to give an orthocline adult. If this is correct Bitrigonocardia may have had a prosocline ancestor. Unfortunately there are no intermediate sized specimens preserved which preclude further comparison of the possible ontogeny.

Superfamily Conocardioidea Miller, 1889

Family Bransoniidae Pojeta \& Runnegar, 1976

\section{Genus Pojetaconcha Waterhouse, 1987}

Type species. - By original designation of Waterhouse (1987, p. 223): Bransonia cressmani Pojeta \& Runnegar, 1976, p. 72, pl. 52, figs 10-14, from the Chatfieldian (Ka1) Perryville Limestone, Lexington Formation, at Mitchellsburg, south of Perryville, Kentucky, USA.

Remarks. - Waterhouse (1987) pointed out that Lower Palaeozoic species previously placed with Bransonia Pojeta \& Runnegar, 1976 differed considerably from this in the ornamentation and placed them in the new genus Pojetaconcha. Waterhouse (1987) distinguished the genus by the strong ribs on the body and snout and the lack of a keel (primary carina) raised above the body. Besides the types species and Bransonia beecheri (Raymond, 1905) other species were not specified by Waterhouse (1987), but tacitly the concept would encompass all Ordovician and Silurian species described as Bransonia by Pojeta \& Runnegar (1976), Pojeta et al. (1977) and Pojeta \& GilbertTomlinson (1977) (Tab. 4; see also Wagner 2016).

\section{Pojetaconcha costulata sp. nov.} Figure 22A-D

Holotype. - RGM.1332206, internal mould from the Öjlemyr chert (Pirgu) at Wilsum, Germany (Fig. 22A, B).

Other material. - RGM. 1332207 from the Öjlemyr chert (Pirgu) at Wilsum, Germany (Fig. 22C, D).

Etymology. - Adjective, from Latin Costulata meaning ribbed, pertaining to the strong ribs on the body and snout of the internal moulds.

Diagnosis. - A small species of Pojetaconcha with 14 or 15 broad and flat-topped radial ribs on body and snout with wide spaces in between. Anteriormost part of snout with fine spaced comarginal lines crossed by denser and finer radial ornamentation. Rostral area only with comarginal ornamentation.

Description. - Steinkern: Conch prosocline with inflated body and weakly concave transition to cone-shaped triangular snout. Preserved length ca $4 \mathrm{~mm}$. Ventral margin of snout weakly convex. Ventral margin of body evenly convex and divergent, but convexity low. Primary carina broad ventrally, narrow and indistinct dorsally. Surface of carina with concave field on posterior part and raised cord-like structure towards the anterior edge. Body and snout with 14 or 15 broad and flat-topped ribs, 7 on the body and 7-8 on the snout. Ribs on body interspaced by flat 

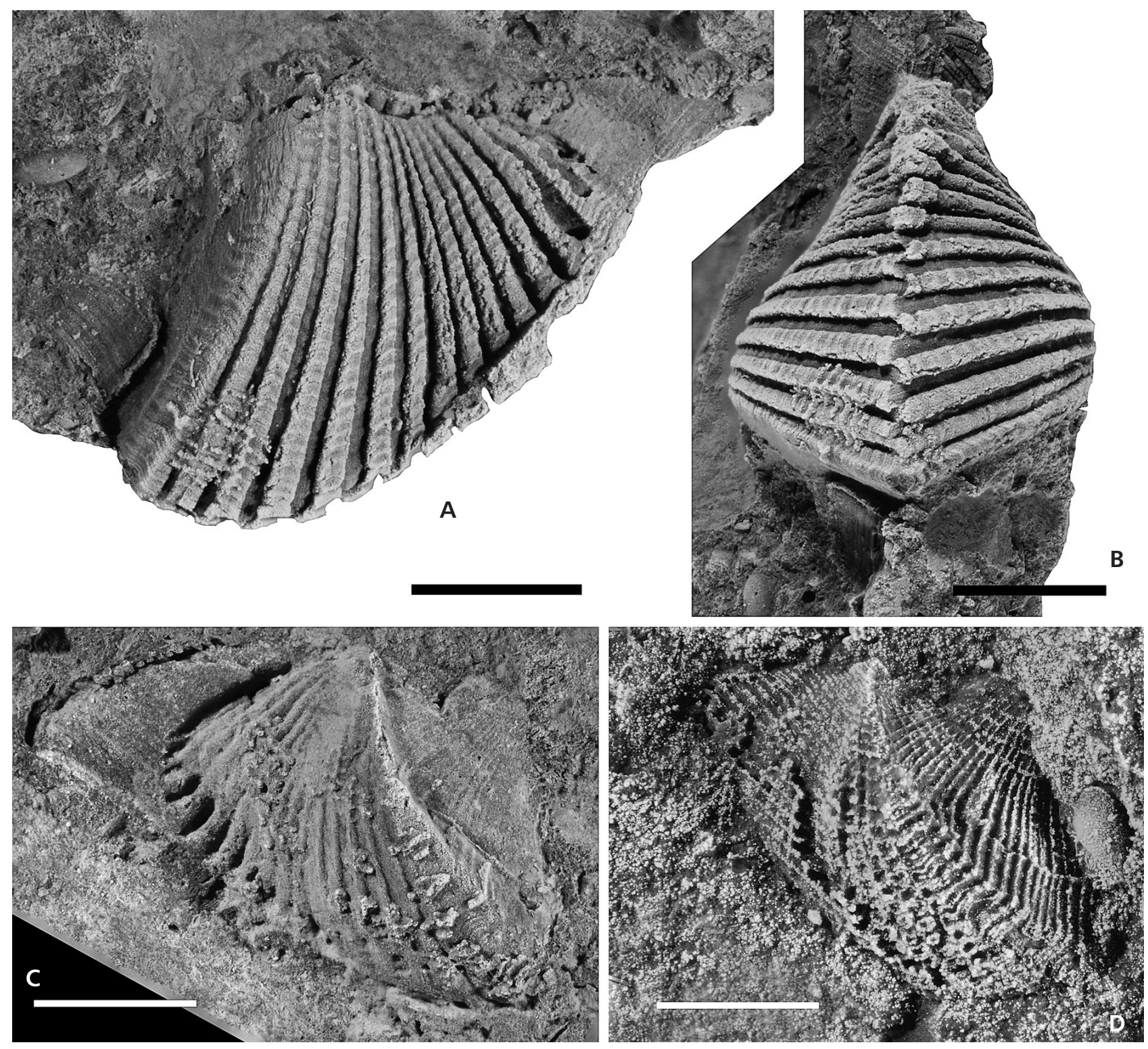

Figure 22. Pojetaconcha costulata sp. nov. • A-B - RGM.1332206, holotype, right lateral and ventral views respectively of steinkern. Öjlemyr chert (Pirgu). Wilsum, Germany. Scale bars for all $=0.1 \mathrm{~cm} . \cdot \mathrm{C}-\mathrm{D}-\mathrm{RGM} .1332207$, left side of steinkern and silicon cast of external mould respectively. Öjlemyr chert (Pirgu). Wilsum, Germany.

grooves of slightly narrower widths. Grooves on snout much narrower than ribs. Anteriormost ribs joined ventrally around narrow tear-drop shaped anterior gape (broadest end anteriorly). Ribs alternate at body commissure. Anterior part of snout with fine lirae crossed by finer densely spaced radial ornamentation. Tip of snout flared out and up to form small wing-like structures. Rostral area nearly flat, low concave with fine comarginal lines, possibly with extended rostrum. Ornamentation on primary carina and ribs consists of spaced, fine, slightly raised lirae with finer lirae in between.

Outer she1l: Primary carina with pseudo-lunulae that continues onto body and snout to form reticulated orna- mentation. Rostral area with reticulate ornamentation where comarginal ribs are slightly stronger.

Remarks. - Two equally sized specimens are attributed to Pojetaconcha costulata sp. nov., although they show slightly different preservation. Specimen RGM.1332206, the holotype, shows the internal mould and appears crisp in the details (Fig. 22A, B). Specimen RGM.1332207 is preserved as both an internal mould with the inner shell layer impressed as well as an external mould from which a silicon cast was made to show the outer shell layer (Fig. 22C, D). They are considered similar because they both have similar coarse and broad ribs that characteristically are joined near 
the ventral margin on the snout, the broad primary carina with pseudo-lunulae on its lower $2 / 3$ only, and a low concave rostral area with dominant commarginal ornamentation on the internal mould. The type species $P$. cressmani is similar in size and in the rounded body compared to $P$. costulata but has fewer ribs and lack a primary carina. The most similar species is $P$. alabamensis from USA which is of the same size, has coarse ribs and a primary carina, but it differs in lacking an inflated body and having a noselike snout. Similar broad and flat ribs are present in $P$. townleyi from Australia but the space in between the ribs are much narrower than in $P$. costulata and a greater part of the snout lacks radial ornamentation. $P$. beecheri from USA differs from $P$. costulata in having more ribs and more prominent comarginal ornamentation while $P$. paquettensis from Canada differs in being larger with thinner radial ribs and finer comarginal ornamentation. $P$. limatula from USA differs in having a very long snout without radial ornamentation. $P$. praepristis from Ireland is only known from the compressed rostral area which precludes comparison (Reed 1952, p. 79, pl. 4, fig. 11). See also Table 4 for details on these taxa.

\section{Conclusions}

(1) A diverse and well-preserved collection of rostroconchs from fluvially transported erratics in the Dutch-German border area have been described.

(2) Taxa from the Haljala group of erratics (Sandbian 2) are represented by the ribeirioid Tolmachovia sublirata sp. nov., Beukeria plicata gen. nov. sp. nov. and Ischyrinia viator sp. nov., while conocardiid taxa from the Pirgu Öjlemyr chert (Katian 4) are represented by Bitrigonocardia lindstroemi (Isberg) and Pojetaconcha costulata sp. nov.

(3) The material is important in demonstrating a greater diversity of Ordovician rostroconchs and showing a broader geographical and temporal range of several taxa. This includes the stratigraphically youngest occurrence of Tolmachovia and the first occurrence of Pojetaconcha outside Laurentia and Australia.

(4) New morphological features include the presence of subordinate radial ornamentation in Tolmachovia, a ventrolateral sinus in Ischyrinia, and the elongated conch, with two thick pegmas and a plicate shell posterior to vertical axis in the new genus Beukeria. The latter adds to the ischyriniid diversity.

(5) The biogeographical significance of the new material highlights the main occurrence of Ischyriniids in Baltica with Ischyrinia probably migrating into Laurentia. A gen- eral exchange of Bitrigonocardia and Pojetaconcha is seen between Laurentia and Baltica in the later part of the Ordovician.

\section{Acknowledgements}

Jaap Beuker, Assen (the Netherlands), and Rolf Smit, Gramsbergen (the Netherlands) are thanked for donating their specimens to Naturalis Biodiversity Center, Leiden (NL). Michael Zwanzig, Berlin, Germany, kindly helped with older German literature. We are grateful for detailed and helpful reviews by Jiří Křǐž and Marika Polechová (both the Czech Republic). Natasja den Ouden at the Naturalis Biodiversity Center (Leiden) kindly provided catalogue numbers for the specimens.

\section{References}

AngELin, N.P. \& LindSTRÖM, G. 1880. Fragmenta Silurica. 60 pp. Samson \& Wallin, Holmia.

AmLER, M.R.W. 2016. Shallow marine Rostroconchia (Mollusca) from the latest Devonian (Strunian) and their significance for rostroconch life style and evolution. Geologica Belgica 19, 111-120. DOI 10.20341/gb.2016.002

AmLer, M.R.W. \& Bartholomäus, W.A. 1998. Ein hippocardiider Rostroconch in einem Hornstein (Ordosilur) von Sylt. Archiv für Geschiebekunde 2, 387-397.

AmLer, M.R.W. \& Gummersbach, K. 2015. Ein pseudobigaleaider Rostroconch aus dem oberordovizischen Boda-Kalkstein des Siljan-Gebietes (Mittel-Schweden). Archiv für Geschiebekunde 7, 311-323.

AmLER, M.R.W. \& LoHREnGEL, A.F. 2015. Ein pseudobigaleaider Rostroconch in einem ober-ordovizischen Geschiebe. Archiv für Geschiebekunde 7, 261-276.

AmLER, M.R.W. \& Rogalla, N.S. 2013. Biogeographical distribution patterns in Early Palaeozoic Rostroconchia (Mollusca). Geological Society London, Memoirs 38, 243-263.

Babin, C., Courtessole, R., Mélou, M., Pillet, J., Vizcãĩno, D. \& Yochelson, E.L. 1982. Brachiopodes (Articulés) et Mollusques (Bivalves, Rostroconches, Monoplacophores, Gastropodes) de l'Ordovicien Inférieur (TremadocienArenigien) de la Montagne Noire (France méridionale). Memoire de la Société des Etudes Scientifiques de I'Aude, Carcassonne, 1982, 1-63.

BARRANDE, J. 1881. Systême Silurien du centre de la Bohême. 1. Recherches Paleontologiques, Vol. VI: Classe des Mollusques. Ordre des Acephales. 342 pp. Barrande \& Waagen, Prague \& Paris.

Bergström, S.M., Chen, X, Gutiérrez-Marco, J.C. \& Dronov, A. 2009. The new chronostratigraphic classification of the Ordovician System and its relations to major regional series and stages and d13 chemostratigraphy. Lethaia 42, 97-107. DOI 10.1111/j.1502-3931.2008.00136.x

BiLlings, E. 1866. Catalogues of the Silurian fossils of the Island of Anticosti, with descriptions of some new genera and species. 93 pp. Dawson Brothers, Montreal. DOI 10.4095/216072 
Bradley, J.H. 1930. Fauna of the Kimmswick Limestone of Missouri and Illinois. Contributions from Walker Museum (University of Chicago) 2, 219-290.

Branson, C.C. 1942. Correction of homonyms in the lamellibranch genus Conocardium. Journal of Paleontology 16, 387-392.

BRANSON, C.C. 1966. Conocardium in the Bromide Formation (Ordovician) of Oklahoma. Oklahoma Geology Notes 26, 78-79.

Caldwell, M.W. \& Chatterton, B.D.E. 1995. Phylogenetic analysis of some Silurian rostroconchs (Mollusca) from northwestern Canada. Canadian Journal of Earth Sciences 32, 806-827. DOI 10.1139/e95-068

EbBestad, J.O.R., FrÝdA, J., WAgner, P.J., HornÝ, R.J., IsAKar, M., Stewart, S., Percival, I.G., Bertero, V., Rohr, D.M., Peel, J.S., Blodgett, R.B. \& Högström, A.S. 2013. Biogeography of Ordovician and Silurian gastropods, monoplacophorans and mimospirids. Geological Society London, Memoirs 38, 199-220.

Eichwald, E. DE 1842. Die urwelt Russlands, durch abbildungen erlaeutert. Zweites heft. 184 pp. Kaiserlichen Akademie der Wissenschafte, St Petersburg.

ENGESER, T. \& RiEdEL, F. 1996. The evolution of the Scaphopoda and its implications for the systematics of the Rostroconchia (Mollusca). Mitteilungen Geologische-paläontologische Institut der Universität Hamburg 79, 117-138.

Etheridge, R. 1878. Notes on a few Silurian fossils from Ayrshire. Proceedings of the Royal Physical Society of Edinburgh 4, 167-176.

GutiérRez-Marco, J.C. 1997. Tolmachovia babini nov. sp., nuevo ribeirioide (Mollusca, Rostroconchia) del Ordovícico Medio de la Zona Centroibérica Española. Geobios 30, 291-298. DOI 10.1016/S0016-6995(97)80034-4

GutiérRez-Marco, J.C. \& AceÑolaza, F.G. 1992. Ribeiria y Tolmachovia (Mollusca, Rostroconchia) en el Ordovício inferior de la Cordillera Oriental Argentina. Zentralblatt für Geologie und Paläontologie 1, 1799-1814.

Harper, D.A.T., Rasmussen, C.M.Ø., Liljeroth, M., Blodgett, R.B., Candela, Y., Jin, J., Percival, I.G., Rong, J., Villas, E. \& ZHAN, R. 2013. Biodiversity, biogeography and phylogeography of Ordovician rhynchonelliform brachiopods. Geological Society London, Memoirs 38, 127-144.

Harrington, H.J. 1938. Sobre las faunas del Ordovícico inferior del Norte argentino. Revista del Museo de La Plata, Nueva Serie, Sección Paleontología, 1, 109-289.

Hisinger, W. 1837. Lethaea Svecica seu Petrificata Svecia, iconibus et characteribus illustrate, 124 pp. Norstedt \& Son, Holmiae.

Hoare, R.D. \& Plas, L.P. JR. 2003. Permian rostroconchs (Mollusca) from Nevada. Journal of Paleontology 77, 873-875. DOI 10.1017/S0022336000044723

HoARe, R.D., Mapes, R.H. \& YANCEY, T.E. 2002. Structure, taxonomy, and epifauna of Pennsylvanian rostroconchs (Mollusca). Paleontological Society Memoir 58, Supplement to Journal of Paleontology 76, 1-30.

DOI 10.1666/0022-3360(2002)76[1:STAEOP]2.0.CO;2

Howell, B.F. \& Kobayashi, T. 1936. A new notostracan genus from the Ordovician of Siberia. Annals of the Carnegie Museum 25, 59-61.
IsAKAR, M. 1997. Ordovician and Silurian bivalves and rostroconchs, 228-232. In RauKas, A. \& TEEDUMÄE, A. (eds) Geology and Mineral resources of Estonia. Estonian Academy Publishers, Tallinn.

IsBERG, O. 1934. Studien über lamellibranchiaten des Leptaenakalkes in Dalarna. 493 pp. Håkan Ohlssons Buchdruckerei, Lund.

Kobayashi, T. 1933, Faunal study of the Wanwanian (basal Ordovician) series with special notes on the Ribeiridae and the ellesmeroceroids. Journal of the Tokyo Imperial University, Faculty of Sciences, Section II Geology, Mineralogy, Geography, Seismology 3, 249-328.

Krause, A. 1877. Die Fauna der sogen. Beyrichien- oder Choneten-Kalke des Norddeutschen Diluviums. Zeitschrift der Deutschen Geologischen Gesellschaft 29, 1-49.

LinNÉ, C. 1758. Systema naturae per regna tria naturae, secundum classes, ordines, genera, species, cum characteribus, differentiis, synonymis, locis. Tomus I. Editio decima, reformata, 824 pp. Salvius, Holmiae.

DOI 10.5962/bhl.title.542

Mazaev, A.V. 2012. Anetshelloida, a new rostroconch order (Mollusca: Rostroconchia). Paleontological Journal 46, 121-131. DOI 10.1134/S0031030112020074

MiLler, S.A. 1889. North American geology and palaeontology for the use of amateurs, students and scientists. $664 \mathrm{pp}$. Western Methodist Book Concern, Cincinnati. DOI 10.5962/bhl.title.18066

MüLDNER, A. 1943. Die ersten Vertreter der Gattung Ischyrinia in nordeutschen Diluvialgeschieben. Zeitschrift für Geschiebeforschung und Flachlandsgeologie 18, 93-96.

Neumayr, M. 1891. Beiträge zu einer morphologischen Eintheilung der Bivalven. Denkschriften der Mathematisch Naturwissenschaftlichen Classe der Kaiserlichen Akademie der Wissenschaften 58, 708-801.

Overeem, I., Weltue, G.J., Bishop-Kay, C. \& Kroonenberg, S.B. 2001. The Late Cenozoic Eridanos delta system in the Southern North Sea Basin: a climate signal in sediment supply? Basin Research 13, 293-312. DOI 10.1046/j.1365-2117.2001.00151.x

PeEL, J.S. 2004. Pinnocaris and the origin of scaphopods. Acta Palaeontologica Polonica 49, 543-550.

Peel, J.S. 2006. Scaphopodization in Palaeozoic molluscs. Palaeontology 49, 1357-1364.

DOI 10.1111/j.1475-4983.2006.00599.x

Peel, J.S. \& HornÝ, R.J. 2004. A new problematic Lower Ordovician univalve mollusc from France. Palaeontology 47, 1629-1639. DOI 10.1111/j.0031-0239.2004.00414.x

Perner, J. 1903. Systême Silurien du centre de la Bohême par Joachim Barrande. Vol. IV Gastéropodes, Tome 1. Texte (Patellidae et Bellerophontidae) et Planches 1 à 89, I-XI. 164 pp. Charles Bellmann, Prague.

PojetA, J. JR. 1987. Class Rostroconchia, 358-380. In BoARDMAN, R.S., Cheetham, A.H. \& Rowell, A.J. (eds) Fossil invertebrates. Blackwell Scientific Publications, Palo Alto.

PojetA, J. JR. \& Gilbert-Tomlinson, J. 1977. Australian Ordovician pelecypod molluscs. Bureau of Mineral Resources, Geology and Geophysics, Bulletin 174, 1-64.

Pojeta, J. JR. \& Runnegar, B. 1976. The palaeontology of 
rostroconch molluscs and the early history of the phylum Mollusca. Geological Survey Professional Paper, United States 968, 1-88.

Pojeta, J. JR., Gilbert-Tomlinson, J. \& Shergold, J.H. 1977. Cambrian and Ordovician rostroconch molluscs from northern Australia. Bureau of Mineral Resources, Geology and Geophysics, Bulletin 171, 1-54.

Pojeta, J. JR., Runnegar, B., Morris, N.J. \& Newell, N.D. 1972. Rostroconchia: a new class of bivalved molluscs. Science 177, 264-267. DOI 10.1126/science.177.4045.264

Raymond, P.E. 1905. The fauna of the Chazy Limestone. The American Journal of Science 20, 353-382.

REED, F.C. 1952. Revision of certain Ordovician fossils from County Tyrone. Proceedings of the Royal Irish Academy B 55, 29-136.

RHEBERGEN, F. 1994. Ordovicische rostroconchen. Grondboor en Hamer 48, 54-58.

Rhebergen, F. 2009. Ordovician Sponges (Porifera) and other silicifications from Baltica in Neogene and Pleistocene fluvial deposits of the Netherlands and northern Germany. Estonian Journal of Earth Sciences 58, 24-37. DOI 10.3176/earth.2009.1.03

Rogalla, N.S. 2005. Paläobiologie und Systematik der neuen Überfamilie Hippocardioidea Pojeta \& Runnegar, 1976 (Rostroconchia, Mollusca). 419 pp. Ph.D. thesis, Philipps-Universität Marburg, Marburg, Germany.

Rogalla, N.S. \& AmLer, M.R.W. 2006a. Revision der Familie Pseudobigaleaidae Hoare, Mapes \& Yancey, 2002 (Mollusca; Rostroconchia). Paläontologische Zeitschrift 80, 167-208. DOI 10.1007/BF02988975

Rogalla, N.S. \& AmLER, M.R.W. 2006b. Revision der Familie Hippocardiidae Pojeta \& Runnegar, 1976 (Mollusca; Rostroconchia). Paläontologische Zeitschrift 80, 238-276. DOI 10.1007/BF02988440

Rogalla, N.S. \& AmLER, M.R.W. 2006c. Taxonomie und Systematik der Hippocardioidea Pojeta \& Runnegar, 1976 [n. superfam.] (Mollusca; Rostroconchia). Paläontologische Zeitschrift 80, 344-383. DOI 10.1007/BF02990209

Rogalla, N.S. \& Amler, M.R.W. 2007. Nomina dubia der Hippocardioidea (Mollusca; Rostroconchia). Paläontologische Zeitschrift 81, 29-70.

DOI 10.1007/BF02988379

RunNEgaR, B. 1978. Origin and evolution of the class Rostroconchia. Philosophical Transactions of the Royal So- ciety of London B 284, 319-333.

DOI 10.1098/rstb.1978.0070

RunNegar, B. \& PojeTA, J. JR. 1974. Molluscan phylogeny: the paleontological viewpoint. Science 186, 311-317. DOI 10.1126/science.186.4161.311

SÁ, A.A. 2008. Moluscos del Ordovicico de la region de Tras-os-Montes (Zona Centroiberica, NE de Portugal). Coloquios de Paleontologia 58, 41-72.

SAlter, J.W. 1851. List of some of the Silurian fossils of Ayrshire,170-178. In Murchison, R.I. (ed.) On Silurian rocks of the South of Scotland. The Quarterly Journal of the Geological Society of London 7.

SÁnCHEZ, T.M. 1998. Rostroconchia (Mollusca, Diasoma) en la Formación San Juan (Ordovícico temprano), Precordillera Argentina. Ameghiniana, Nota Paleontológica 35, 345-347.

SoOT-RYEn, H. 1960. The Middle Ordovician of the Oslo region, Norway. 12. Notostraca and Conchostraca. Norsk Geologisk Tidsskrift 40, 123-131.

Teichert, C. 1930. Der erste europaische Vertreter der Gattung Ischyrinia Billings (Eucrust. Notostr.) in der Lyckholm-Stufe von Estland. Paläeontologische Zeitschrift 12, 130-134. DOI 10.1007/BF03044505

ThORAL, M. 1935. Contribution a l'etude paleontologique de l'Ordovicien Inferieur de la Montagne Noire et revision sommaire de la faune Cambrienne de la Montagne Noire. 326 pp. Imprimerie de la Manufacture de la Charité (PierreRouge), Montpellier.

Van Keulen, P.S.F., Smit, R. \& Rhebergen, F. 2012. Ordovizische Lavendelblaue Hornsteine in miozänen bis altpleistozänen Ablagerungen des "Baltischen Flußsystems?. Archiv für Geschiebekunde 6, 155-204.

WAgner, P.J. 1997. Patterns of morphologic diversification among the Rostroconchia. Paleobiology 23, 115-150. DOI 10.1017/S0094837300016675

WAGNER, P.J. 2016. Taxonomic occurrences of Pojetaconcha recorded in the Paleobiology Database. Fossilworks. http://fossilworks.org.

Waterhouse, J.B. 1987. Late Palaeozoic Mollusca and correlations from the South-East Bowen Basin, East Australia. Palaeontographica A 198, 129-233.

Wilson, A.E. 1956. Pelecypoda of the Ottawa Formation of the Ottawa-St. Lawrence Lowland. Geological Survey of Canada, Bulletin 28, 1-102. DOI 10.4095/101527 